\title{
Information and Communications Technology (ICT) and Trade in Emerging Market Economies
}

\author{
Lirong Liu* \\ Hiranya K. Nath ${ }^{*}$,
}

(February 2013)

\begin{abstract}
This paper examines the effects of information and communications technology (ICT) on international trade in emerging markets. Using panel data for 40 emerging market economies (EMEs) for a period from 1995 to 2010, we estimate fixed effects models of exports and imports with ICT as the main explanatory variable of interest. Our ICT variables include the growth of telecom investment, international Internet bandwidth, Internet subscriptions per 100 people, and the number of Internet hosts per 100 people. The first two variables represent ICT infrastructure while the last two represent the use of ICT. We use the share of total exports and of total imports in GDP as the dependent variables. Additionally, we consider the GDP share of exports and imports for goods and services separately. The main control variables are: per capita GDP growth, population growth, and country and year fixed effects. The empirical results overwhelmingly suggest that Internet subscriptions and Internet hosts have significant positive impacts on both export and import shares in EMEs. Thus, the trade enhancing effect of ICT does not depend on ICT infrastructure or ICT capability per se but on its use. This result is robust to a number of sensitivity checks: generalized method of moments (GMM) estimation with lagged independent variables as instruments; inclusion of all four ICT variables together; shorter sample period; a subsample of EMEs; dynamic specification with lagged dependent variable; and an alternative model specification with additional variables. These results suggest that policies to encourage the use of ICT would have a positive impact on trade in EMEs.
\end{abstract}

Keywords: Information and Communication Technology (ICT); Emerging Market Economy (EME); Exports; Imports; Telecom investment; Internet bandwidth; Internet subscriptions; Internet hosts

JEL Classification: F12; F14; F15

${ }^{*}$ Department of Economics and International Business, Sam Houston State University, Huntsville, TX $77341-2118$

† Corresponding author: eco hkn@shsu.edu 


\section{Introduction}

Information and communications technology (ICT) has pervasive effects at micro as well as macro level of an economy. Some macro-level studies (e.g., Jorgenson 2001; Stiroh 2002) show that ICT advances in the 1990s raised productivity and contributed to growth. The use of ICT has been shown to have important implications for employment and wage as well. Several studies (e.g. Autor et al. 1998; Autor et al. 2003; Acemoglu and Autor 2010) argue that ICT has increased the demand for skilled workers and has been largely responsible for growing wage gap between skilled and unskilled workers. Although there are a few exceptions, most of these studies focus on the U.S. and other developed countries. ${ }^{1}$

This paper examines the effects of ICT on exports and imports in emerging market economies (EMEs). There are several intuitively plausible mechanisms through which ICT may affect the flows of international trade. First, the use of ICT may reduce the fixed entry cost into a market and thus stimulates exports. As Freund and Weinhold (2004) discuss, these fixed costs include the costs of finding out information about the market (search cost), advertising, and establishing a distribution network. Second, international transactions often require advance planning that involves handling uncertainty. Some of these uncertainties are associated with the delay in acquiring and transmitting relevant information. The use of ICT reduces such delays and makes planning more efficient and accurate. Consequently, the volume of trade between countries is expected to go up. Finally, ICT may directly facilitate international trade in services, particularly information-intensive services. ${ }^{2}$ These services involve creating, processing, and communicating information. As ICT advances lower the costs of these processes, information-intensive services can be produced and delivered anywhere in the world. Furthermore, ICT facilitates global disaggregation of the production process for information-intensive services and thereby increases trade in those services. ${ }^{3}$ This paper is not intended to examine any particular mechanism because more than one mechanism may be at work simultaneously and it is extremely challenging to separate out their effects empirically, particularly when we examine cross-country experiences. Thus, we investigate the overall impact of ICT that may affect trade through various mechanisms.

There have been a few studies that examine the effects of ICT on trade. For example, Freund and Weinhold (2002) investigate how the Internet affects international trade in services. They consider U.S. exports and imports of 14 service items to and from 31 countries between 1995 and 1999 and find that Internet development in those countries has significant positive impact on bilateral trade with the U.S. They further extend this analysis to cover merchandise trade and to

\footnotetext{
${ }^{1}$ Haacker (2010) examines the effects of ICT equipment investment on growth for low and lower middle income countries. In a recent paper, Dimelis and Papaioannou (2011) investigate the effects of ICT on aggregate technical efficiency for a group of 42 countries that include both developed and developing countries.

${ }^{2}$ Examples of such services include various customer services, education, medical transcriptions, tax returns, web design etc.

${ }^{3}$ See Apte and Mason (1995) and Mithas and Whitaker (2007) for a discussion on global disaggregation of information-intensive services.
} 
include 56 countries in a subsequent study (Freund and Weinhold 2004). In this article, they also include a theoretical model to explain how the Internet potentially affects trade. Fink et al (2005) find evidence of significant influence of communication costs on bilateral trade in the data for 107 countries in 1999. Using data for 98 countries, Clarke and Wallsten (2006) further show that access to the Internet improves export performance in developing countries and they export more to developed countries. Vemuri and Siddiqi (2009) analyze panel data for 64 countries for a period between 1985 and 2005 and conclude that ICT infrastructure and the availability of Internet for commercial transactions have a positive and significant impact on the volume of international trade. Using data for 175 countries, Demirkan et al (2009) also find evidence of bilateral trade enhancing effect of ICT use. Choi (2010) provides further evidence of Internet usage raising services trade for 151 countries for a period from 1990 to 2006. More recently, Mattes et al (2012) examine the effects of availability and use of ICT on trade using data from the European Union (EU) countries. Although they do not find any significant impact of ICT on EU trade, their results suggest that trade is enhanced if both trading partners are advanced users of ICT. ${ }^{4}$

In contrast to the existing studies, we focus on 40 emerging market economies (EMEs) during the period between1995 and 2010. These countries have witnessed substantial increases in trade and ICT adoption during this period and any evidence of a significant relationship between these two phenomena will have important policy implications. Most previous studies (Freund and Weinhold 2002 \& 2004; Clarke and Wallsten 2006; Choi 2010) use the number of Internet hosts as the main independent variable of interest whereas we use four alternative variables that capture different aspects of ICT with the potential impacts on trade. Furthermore, we estimate the export and import models separately for goods and services. Finally, like Choi (2010), we use total exports and total imports for each country instead of bilateral trade between two countries as used in most previous studies. $^{5}$

Thus, we estimate fixed effects models of exports and imports to examine the effects of ICT on trade. Our ICT variables include growth of telecom investment, international Internet bandwidth, Internet subscriptions per 100 people, and the number of Internet hosts per 100 people. We use the percentage share of total exports and of total imports in GDP as the dependent variables. Additionally, we consider the GDP share of exports and imports for goods and services separately. The main control variables are: GDP per capita growth, population growth, and country and year fixed effects. The empirical results overwhelmingly suggest that Internet subscriptions and Internet hosts have significant positive impacts on export as well as import shares in EMEs. This result is robust to a number of alternative specifications.

The rest of the paper is organized as follows. Section 2 includes a detailed discussion of the data and methodology used for the empirical analysis presented in this study. In section 3, we present and

\footnotetext{
${ }^{4}$ Fleming et al. (2009) and Thiemann et al (2012) examine the effects of ICT, particularly use of mobile phone and fixed telephone, on trade in flowers and trade in fruits and vegetables respectively.

5 The advantage of using bilateral trade data is that the empirical analysis can be based on the gravity model framework that provides a clear theoretical foundation. It also allows to control for a wider range of unobserved heterogeneity.
} 
discuss the empirical results for our baseline model. Section 4 presents the sensitivity analysis results. In the last section, we summarize and include a few concluding remarks.

\section{Data and Methodology}

\subsection{Data}

We compile a list of 40 EMEs from five different sources: the FTSE Group, Morgan Stanley Capital International (MSCI), Standard and Poor (S\&P), Dow Jones (DJ), and Banco Bilbao Vizcaya Argentaria (BBVA) Research. We exclude a few countries that have been identified as EMEs by one or more of these agencies, primarily due to a lack of relevant data for those countries. Table 1 lists the countries in our sample and, for each country, indicates which agency (agencies) has (have) identified it as an EME in its (their) latest report (reports). Note that 19 countries have been listed as EMEs by each of these five agencies. ${ }^{6}$

\section{[Insert Table 1]}

For our empirical analysis, the main sources of data are the World Development Indicators (WDI) and the Global Development Finance (GDF), compiled and published by the World Bank, and the World Telecommunication ICT Indicator database compiled and maintained by the International Telecommunication Union (ITU). Annual data on total exports (of goods and services together) and total imports are available in both current prices and 2000 USD constant prices from WDI. However, exports and imports data on goods and services separately are available only in current USD prices. In order to convert the current price export and import values for goods and services into constant prices, we first calculate an export deflator and an import deflator from current and constant price total exports and imports data mentioned above. We then apply the export deflator to both goods and services exports and import deflator to both goods and services imports. ${ }^{7}$ Our sample covers a period from 1995 to 2010. Although the choice is primarily dictated by the earliest and the latest year for which data on some of the ICT variables are available, this is also the period that witnessed significant expansion of trade and the use of ICT in most EMEs.

It is almost impossible to find a single measure of ICT that reflects all different aspects of this general-purpose technology. ${ }^{8,9}$ Previous studies use the number of Internet hosts (Freund and

\footnotetext{
${ }^{6}$ South Korea (Republic of Korea) has been listed as an EME by three of these five agencies. The FTSE group and S\&P do not list it as an EME. By most measures, South Korea is at a much advanced stage of development.

7 A common deflator for both goods and services exports (imports) may lead to overestimation or underestimation of the real values due to a potential change in relative prices between goods and services. However, it is not possible to apply separate deflators due to a lack of appropriate data.

${ }_{8}$ Because of its broader application across different sectors, ICT is referred to as a general-purpose technology. For example, see Basu and Fernald (2007).

${ }^{9}$ ITU now publishes data on a composite indicator called the ICT Development Index (IDI) that combines seven variables representing ICT readiness, ICT use, and ICT capability. As of now, the data are available for 2007, 2009, 2010, and 2011 only. Mattes et al (2012) use this index in their study. They construct data for
} 
Weinhold 2002 \& 2004; Clarke and Wallsten 2006; Choi 2010) or/and the number of telephone lines, personal computers, and Internet users (Vemuri and Siddiqi 2009). We use four alternative variables that capture different aspects of ICT and have potential impacts on the growth of exports and imports. These ICT variables are: total annual investment in telecom, international Internet bandwidth (Mega Bits per second), total fixed (wired) broadband Internet subscriptions per 100 people, and the number of Internet hosts per 100 people. While the first variable reflects the building of ICT infrastructure, the second variable is a measure of technical capability for international transmission of data and communications. In contrast, the third and fourth variables indicate proliferation of ICT uses for obtaining and transmitting information. Broadly, we divide these four variables into two categories: the first two are ICT infrastructure variables and the third and fourth are ICT use variables. This classification is consistent with the framework for ITU's ICT development index. The availability of data on these variables varies across countries and over time. For some countries, data are missing for several years. The data on the number of Internet hosts are available only for six years between 1999 and 2004. The telecom investment data are available in current USD. It is almost impossible to find data on prices of telecom capital goods by countries. However, it may be noted that prices of most ICT capital equipment have declined worldwide over last two decades. Therefore, it is not unreasonable to use the communications equipment price indices for the U.S., obtained from the Bureau of Economic Analysis (BEA), as harmonized deflators to construct constant USD data on telecom investment for all countries in our sample. ${ }^{10}$

Besides these variables of interest, we use a number of control variables that include per capita GDP and population obtained from WDI. Although we include these two control variables in our baseline model specification, we consider additional control variables in our sensitivity analysis. For example, we obtain data on nominal exchange rates from Penn World Table 7 and convert them into real exchange rates using the Consumer Price Index (CPI) data for the U. S. and the respective countries. The CPI data are available from WDI. Data on GDP of the rest of the world (World GDP - Home Country GDP), Foreign Direct Investment (FDI) net inflow in current USD, gross fixed investment in both current and constant USD, and average tariff rates (in percentages) are obtained from WDI and GDF. We use an investment deflator calculated from gross fixed investment data to convert FDI net inflow from current USD into constant USD. Finally, annual data on M2 money supply are obtained from GDF. Appendix Table A.1 includes a description of the variables along with the period of availability and the source of the data.

\section{[Insert Table 2]}

The summary statistics of the dependent variables, the ICT variables, and the control variables for the baseline specification are presented in Table 2. We use the percentage share of exports and imports in GDP as the dependent variable in our empirical model specifications. ${ }^{11}$ This table indicates that there are wide variations in average GDP shares of exports and imports - both for

additional years using the underlying data for the EU countries. However, data on some of these variables are not uniformly available for the EMEs that we consider in the current study.

${ }^{10}$ See Schreyer (2000) for a discussion on using a harmonized deflator.

${ }^{11}$ Clarke and Wallsten (2006) use export share in GDP as the dependent variable. 
goods and services - across the countries. Furthermore, the year-to-year volatility of export and import shares also varies widely. Among the variables of interest, the growth rate of telecom investment during the sample period, averaged across the 40 EMEs, is about $13 \%$ and it varies between a minimum of $-11 \%$ in Argentina and a maximum of $67 \%$ in Ukraine. The natural $\log$ of bandwidth averages at 7.57 with a minimum of 3.64 for Mauritius and a maximum of 10.34 for Czech Republic. The broadband Internet subscriptions average at 5.04 per 100 people that vary between a minimum of 0.05 for Bangladesh and a maximum of 19.79 for South Korea. The average number of the Internet hosts per 100 people is 0.64 with a minimum of 0.0004 in Bangladesh and a maximum of 3.96 in South Korea. Furthermore, there are significant cross-country variations in the average per capita GDP growth rate and the average population growth rate, the two major control variables in our model.

\section{[Insert Table 3]}

In order to get a sense of how the ICT variables may be correlated with the trade variables, we calculate correlation coefficients. Table 3 presents the average correlation coefficients (averaged across countries) along with the minimum and maximum. The average correlations are all positive. However, they are stronger for Internet bandwidth, Internet subscriptions, and Internet hosts. In general, these correlations are stronger for goods trade than for services trade.

\subsection{Methodology}

We estimate fixed effects panel data models for our empirical analysis. We estimate two sets of equations: the first set for three export variables and the second for three import variables. The export variables are: percentage share of total exports in GDP, goods export share in GDP, and services export share in GDP. The import variables are: percentage share of total imports in GDP, goods import share in GDP, and services import share in GDP. On the right-hand side of these models, we include one of the ICT variables: telecom investment growth, natural log of bandwidth, Internet subscriptions per 100 people, and the Internet hosts per 100 people, together with other control variables, country fixed effects, and year fixed effects. ${ }^{12}$ Thus, we estimate a total of 24 models, with 6 models for each ICT variable. Overall, our model takes the following form:

12 We take into account the following considerations while deciding whether to include these ICT variables in growth rate, log-level, or levels. First, we conduct panel unit root tests on all these ICT variables. The conventional test procedures overwhelmingly reject the null of unit root for last three variables. For telecom investment, we have mixed results and, therefore, we decide to include this variable in growth rate. Second, by using Internet hosts per 100 people and Internet users per 100 people we control for the size of the country. In this case, our strategy is similar to Clarke and Wallesten (2006) who use Internet hosts per 100 people as the relevant ICT variable. Although Freund and Weinhold (2002) use log of total number of Internet hosts arguing that scaling by population may understate the importance of the Internet in large countries like India and China, their robustness checks with this variable scaled by population gives them qualitatively similar results (Footnote 5, Freund and Wenhold 2002). Third, International bandwidth represents technical capacity and does not depend on the size of the population. Transforming it into the logarithmic scale allows us to interpret the effect of a percentage change on trade shares in a meaningful way. Note that we do not report the unit root test results and interested readers may obtain them from the authors. 


$$
S_{i t}=\alpha_{i}+\delta Y_{t}+\beta^{\prime} I C T_{i t}+\gamma^{\prime} Z_{i t}+\varepsilon_{i t}
$$

where $S_{i t}$ is the percentage share of exports (or imports) in GDP for country $i$ in year $t, \alpha_{i}$ is the country fixed effect; $Y_{t}$ is the year (time) fixed effect; $I C T_{i t}$ is the ICT variable of interest; $Z_{i t}$ is the vector of control variables; $i$ indexes country with $i=1,2, \ldots, N$; and $t$ indexes time with $t=$ $1,2, \ldots, T \cdot{ }^{13}$

In the baseline specification, we choose per capita GDP growth and population growth along with country and year fixed effects as the control variables. This is the most parsimonious specification that can be estimated with the most available data. This is also consistent with the gravity model that has been the workhorse of most empirical trade models ${ }^{14}$ However, unlike some other studies (e.g.,Vemuri and Siddiqui 2009), we include the growth rates of the first two control variables to avoid the potential spurious regression problem due to the presence of unit root in the data generating process for each of these variables. ${ }^{15} \mathrm{We}$ do not explicitly include distance in our model. Since we use total exports from one country to all its trading partners and total imports into one country from all its trading partners, we may include an average distance between the country and all its trading partners. However, in our model specification, country fixed effects will capture the effect of this time-invariant average distance and, therefore, we do not include it separately. The growth of per capita GDP measures a country's economic growth that reflects improvements in standard of living. As a country grows, the import demand is expected to go up due to greater consumption and investment demand. The effect on exports is not clear a priori. While as growth takes place, the economy may increase its exports due to increased production, an increase in domestic demand may, however, compete with external demand and thereby lower exports. Furthermore, economic growth as reflected in per capita GDP growth also captures improvement in infrastructural capacity which is crucial for international trade. In that case, we would expect it to have a positive impact on both exports and imports.

Like per capita GDP growth, the effect of population growth on exports is ambiguous a-priori. While, by increasing labor supply, it may increase domestic production and exports, a growing population can reduce exports by creating domestic demand. However, population growth is likely to increase the demand for imports. While the country fixed effects would capture the effects of time-invariant country-specific factors, the year fixed effects are expected to capture the effects of global events that may affect trade in all countries in the sample.

We use panel least square (PLS) method to estimate the baseline model. ${ }^{16}$ The country fixed effects are expected to capture much of the heterosckedasticity among the countries while the year

\footnotetext{
${ }^{13}$ Note that, by including percentage share of exports and imports in GDP, we are focusing on "accelerated growth" or "accelerated decline" effects of ICT. If both exports (imports) and GDP grow (or decline) proportionately, there will be no change in the percentage share of exports (or imports) in GDP. Thus, a positive (or a negative) effect on export or import share indicates a growth (decline) accelerating effect of ICT. ${ }^{14}$ See, for example, Kimura and Lee 2006.

15 Using conventional panel unit root tests, we find overwhelming evidence of unit root in the level of these variables. The unit root results are not reported but can be obtained from the authors.

${ }^{16}$ Choi (2010) uses this method.
} 
fixed effects are expected to control for cross-correlations across countries. We rely on pooled Durbin-Watson (DW) test statistics to examine if the estimated residuals are serially correlated. We further estimate a dynamic version of the baseline model with 1-year lagged dependent variable on the right hand side to check if the baseline model estimates are robust to the presence of autocorrelation. We report the results in the section on sensitivity analysis (Section 4). Since in our models the treatment takes place at the country level, the reported standard errors are clustered at that level.

\section{Empirical Results for The Baseline Model}

As discussed above, the baseline specification includes an ICT variable, per capita GDP growth rate, population growth rate, country fixed effects, and year fixed effects. We first report the estimation results for the exports equations and then for imports. We use all available data for 40 countries in our sample.

\subsection{Exports}

Table 4 presents the estimation results for the baseline model for exports. Columns (1) - (4) include the coefficient estimates for regression equations with total export share in GDP as the dependent variable. Of all the ICT variables, telecom investment growth has a negative and significant (at the $10 \%$ level) and international Internet bandwidth has a negative but statistically insignificant effect on export share. The coefficient estimates for the remaining two ICT variables, namely broadband Internet subscriptions per 100 people and the number of Internet hosts per 100 people, are positive and statistically significant at the $1 \%$ level. The coefficient estimates for these two variables indicate that an increase in Internet subscriptions and Internet hosts per 100 people by 1 will raise the export share, on an average, by 0.73 and 0.72 percentage point respectively. That is, if broadband Internet subscriptions increase by 10,000 from the current average of 50,400 in every 1 million population, exports as a share of GDP will increase from an average of $44.84 \%$ (Table 2) to $45.57 \%{ }^{17}$ Furthermore, an addition of 10,000 Internet hosts to the current average of 6,400 per 1 million people will have a very similar effect on the total export share.

[Insert Table 4]

Columns (5) - (8) include the coefficient estimates for the models with goods export share in GDP as the dependent variable while columns (9) - (12) report the corresponding estimates for the

\footnotetext{
${ }^{17}$ It is difficult to assign dollar values as both exports and GDP may increase. But, for a GDP of USD 100 billion, this roughly translates into an increase of USD 1.34 billion in exports (assuming that GDP increases only through the increase in exports). Since exports are a component of GDP, we obtain this figure by solving the following equation for $\Delta \mathrm{X}$ :

where $\Delta X$ is the increase in exports.

$$
\frac{44.84+\Delta X}{100+\Delta X}=0.4557
$$
}


models with services export share as the dependent variable. ${ }^{18}$ According to these results, telecom investment growth and Internet bandwidth do not matter either for goods export or for services export. Internet subscriptions have a positive and significant effect on goods as well as services exports. Furthermore, although the estimated coefficient of Internet hosts is positive and highly significant for goods export, it is negative but statistically insignificant for services export. This is interesting because it indicates that while broadband Internet connections help exports of both goods and services, the positive impact of Internet hosts (as we observed in column 4 above) is entirely on merchandise exports. This is in contrast with the results obtained by Freund and Weinhold (2002) and Choi (2010). However, one needs to recognize that Freund and Weinhold (2002) considered services exports from the U.S. and Choi (2010) uses a sample of 151 countries including many developed countries that are the major exporters of services, particularly information-intensive services. ${ }^{19}$ Among the EMEs, barring a few exceptions (like India), most countries export relatively small quantity of services that primarily include physical services such as transportation, that are not likely to be significantly influenced by ICT. Further, note that the estimated coefficients for services exports are quantitatively much smaller.

Among the control variables, per capita GDP growth has a negative and statistically insignificant effect in most cases. It has a significant positive effect on total and goods export shares with Internet hosts as the relevant ICT variable. Population growth has a positive and statistically significant effect on total and goods export share in 7 out of 8 cases. In the case of services exports, the estimated coefficients are not statistically significant. Note that the magnitudes and signs of the coefficient estimates for each control variable cannot be directly compared across these model specifications as the estimates are based on different samples depending on the data availability for corresponding ICT variables. As for the significance of their signs, the estimated coefficients for the control variables reflect the net effects of various forces working in different directions as we have discussed in Section 2.

Overall, the results suggest that ICT infrastructure, as represented by telecom investment and international Internet bandwidth, by itself does not have any significant impact on exports from the EMEs. In contrast, evidence strongly suggests that the use of ICT as reflected by Internet subscriptions and the number of Internet hosts, does increase exports from the EMEs. Thus, building infrastructure and acquiring capability will not help with exports from these countries unless and until they are put to use. Although our results do not point to a particular mechanism through which the use of ICT may have increased exports (and it may vary across countries), it can be inferred that use of the Internet reduces transactions costs associated with export and thereby has a positive impact on it. These costs include the costs of gathering, processing, and communicating information.

\footnotetext{
${ }^{18}$ In general, the coefficient estimates for goods export share and services export share should add up to the coefficient estimate for total export. However, for some countries, data are not available by these two categories for all the years for which data on total exports are available. That is why they do not exactly add up.

${ }^{19}$ For an overview of major exporters and importers of services, see Apte and Nath (2012).
} 


\subsection{Imports}

In Table 5, we present the estimation results for the baseline model for imports. The coefficient estimates for the regression equations with total import share in GDP as the dependent variable are included in columns (1) - (4). Among the ICT variables, telecom investment growth has a negative and statistically significant (at the 10\% level) effect while the rest three have significant positive impacts on import share. The coefficient estimates are statistically significant at the $1 \%$ significance level for each of these three ICT variables. According to the coefficient estimates, a $1 \%$ increase in Internet bandwidth raises the import share by 1.51 percentage point. It implies that if International Internet bandwidth increases by $1 \%$ from its average of 47,888 megabits per second, imports as a share of GDP will increase from an average of $45.62 \%$ to $47.13 \%$. Furthermore, as Internet subscriptions and Internet hosts increase by 1 per 100 people, import share rises by 0.63 and 0.62 percentage point respectively. That is, an addition of 10,000 Internet subscriptions to the current average of 50,400 per 1 million people will increase imports as a share of GDP from an average of $45.62 \%$ to $46.25 \%$. Adding 10,000 Internet hosts to the current average of 6,400 per 1 million population will have a very similar effect on import share.

\section{[nsert Table 5]}

Columns (5) - (8) include the coefficient estimates for the models with GDP share of goods imports as the dependent variable while columns (9) - (12) report the corresponding estimates for the models with services import share as the dependent variable. The coefficient estimates for the ICT variables in both sets of equations are qualitatively similar to those in total import share equations for most cases. The only differences are: the estimated coefficient for telecom investment growth is no longer statistically significant for goods imports and it is positive (but not statistically significant) for services imports. Furthermore, the coefficient estimates for bandwidth is weakly significant for goods imports and not statistically significant for services imports. As in the case of exports, the estimated coefficients in the models for services imports are quantitatively much smaller.

Among the control variables, per capita GDP growth has a positive but, in 7 out of 8 cases, statistically insignificant effect on total and goods import share. The coefficient estimates are negative and, in 3 cases, statistically significant for services imports. Population growth has positive and, in most cases, statistically significant effects on imports.

Overall, our results indicate that ICT infrastructure building through telecom investment does not help with imports. However, in contrast to exports, international internet bandwidth has a positive impact on imports although the evidence is much weaker for services imports. Services imports to many of the EMEs include information-intensive services such as computer programming, financial services that require ICT capability for the delivery of those services. The positive and significant coefficient estimate for Internet bandwidth seems to have captured this trade pattern. Furthermore, like in the case of exports, the use of ICT for acquiring and transmitting information as captured by Internet subscriptions and Internet hosts have a significant positive impact on import shares. Thus, it is primarily through the use of the Internet that ICT increases 
imports into the EMEs. The low cost of information gathering and, in some cases, the low cost of delivering services may have generated this positive impact.

The fact that the estimated ICT coefficients for services trade (both exports and imports) are smaller than those for goods trade needs some explanation. For most of these EMEs, services trade primarily include physical services such as travel and transportation, in which case the effects of ICT would presumably be smaller than in the case of trade in information-intensive services such as computer and data processing services or financial services. To give an example, our sample includes major oil exporting countries like Iran, Kuwait, and Nigeria where the transportation services associated mainly with oil exports (oil pipeline, port services etc.) are a substantial part of services exports (they average 47\%, 55\%, and $56 \%$ respectively over the years for which data are available). These services are not likely to be significantly affected by ICT. Consequently, the estimated coefficients that represent average impacts of ICT on services exports are expected to be relatively smaller.

\subsection{Endogeneity}

Our empirical model is based on the assumption that the causality runs from ICT to export and import shares. However, it is possible that exports and imports may also cause ICT ${ }^{20}$ Similarly, the causality may also run from trade to other control variables. Furthermore, both ICT (and other right-hand side variables) and exports/imports may be caused by a third factor that is not observable. These possibilities give rise to the endogeneity problem that has been widely recognized in the literature. Clarke and Wallsten (2006) and Vemuri and Siddiqi (2009) extensively discuss this issue in the context of ICT and trade. ${ }^{21}$ There are serious consequences of endogeneity. In the presence of endogeneity, least square method can produce biased and inconsistent parameter estimates and hypotheses tests can be seriously misleading. One way to handle endogeneity is to build a theoretical model that clearly establishes a unidirectional causality from the right-hand variables to the left-hand side variable in the regression model. Freund and Weinhold (2004) adopt this strategy. Since we do not have a theoretical model, we have to rely on purely empirical strategies. We first include lagged

${ }^{20}$ In our model, at least in two cases it is unlikely that trade would cause ICT, For example, when we use the growth of telecom investment as the ICT variable, it is the growth between last year and the current year whereas the dependent variable - the export (import) share - is for the current year. Therefore, it is not intuitively clear how the export (import) share in current period will cause the growth in investment since last year. For the same reason, trade in current period does not seem to cause growth of per capita income between last year and the current year, a major control variable that we have included in our model. In order to verify this, we estimate fixed effects regression models of per capita GDP growth on export and import shares. The estimated coefficients are statistically insignificant. These results are held as evidence against the potential reverse causality from trade to per capita GDP growth. Note that there is a substantial literature (e.g., Frankel and Romer 1999) that argues that trade causes growth. Furthermore, while an increase in export and import share may cause increases in Internet bandwidth and the number of Internet hosts, it does not seem to be the case with Internet subscriptions.

${ }^{21}$ Clarke and Wallsten (2006) use a country's regulation of data services as an instrument for Internet hosts in order to control for endogeneity. In contrast, Vemuri and Siddiqi (2009) use instrumental variable approach of Hausman and Taylor (2009). We also use a similar approach. 
ICT variables (rather than including them contemporaneously) on the right-hand side. In particular, we use 1-, 2-, and 3-year lag of the ICT variables. ${ }^{22}$ Freund and Weinhold (2004) use 1-year lag in one of their specifications. The coefficient estimates for the lagged ICT variables are presented in Table $6 .{ }^{23}$ In most cases, they are qualitatively similar to the coefficient estimates in Table 4 and 5. Only in a few cases the signs of the estimated coefficients change but they are all statistically insignificant before and after we replace contemporaneous ICT variable with a lagged ICT variable. Furthermore, the estimated coefficients of lagged Internet subscriptions and Internet hosts are positive and statistically significant at least at the 5\% level. In terms of magnitude, Internet subscriptions have the largest impact on trade variables at 2-year lag while Internet hosts have the largest impact at 3-year lag.

\section{[Insert Table 6]}

The second strategy that we adopt is to use the instrumental variable (IV) method. Although it is intuitively appealing, the most challenging issue is to find the appropriate instrument. However, following Hausman and Taylor (1981), we can use lagged values of potentially endogenous variables as instruments. ${ }^{24}$ We then use a panel GMM estimation method, as in Choi (2010). We use 1-year lag of the ICT variables, 1 and 2-year lags of per capita GDP growth, and 1-year lag of population growth as the instruments. Table 7 presents the results. Both telecom investment growth and bandwidth have positive but, in most cases, statistically insignificant effects on export and import shares. The estimated coefficients for internet subscriptions are positive and highly significant. Finally, internet hosts have positive impacts in all but the case of services exports. However, the coefficients are statistically significant only for goods exports and total imports. Overall, the results are consistent with those in Table 4 and 5.

\section{[Insert Table 7]}

We also conduct Hansen's J test for the validity of the instruments and report the estimated test statistics and associated $p$-values at the bottom of Panel B. The high $p$-values indicate that the instruments are valid. Only in the case of export share with bandwidth as the relevant ICT variable, we reject the null that instruments are valid at the 5\% level. However, an alternative set of instruments (1-year lag of telecom investment growth and per capita GDP growth, and 1 and 2-year lag of population growth) is more appropriate instruments in this case. When these instruments are used, there is little change the estimated coefficient of the ICT variable.

\section{Sensitivity Analysis}

In order to examine if the results with regard to the effects of ICT on exports and imports are robust, we estimate several alternative specifications of our regression models. First, we include all

\footnotetext{
${ }^{22}$ Using more than 3 lags reduces the number of usable observations particularly when the number of Internet hosts is used as the relevant ICT variable.

${ }^{23}$ For comparison, we adjust the sample period so that all three specifications include same number of periods.

${ }^{24}$ Vemuri and Siddiqi (2009) use this approach.
} 
four ICT variables together in the regression equations for exports and imports. Since most of these variables are highly correlated, it would be interesting to see which ICT variables remain statistically significant in the presence of the others. As for the correlations among the ICT variables, Internet bandwidth is positively correlated with telecom investment growth, Internet subscriptions, and Internet hosts with correlation coefficients of $0.40,0.52$, and 0.46 respectively. Furthermore, Internet subscriptions and Internet hosts are strongly positively correlated with an estimated coefficient of 0.66 . Telecom investment growth is weakly correlated with Internet subscriptions and Internet hosts. Second, we use a shorter sample period, 2002 -2008, to estimate the baseline model. This period witnessed significant steady growth of both exports and imports in the EMEs in our sample. Also, there was substantial proliferation of ICT during this period. We cut off the sample period in 2008 because most countries experienced a large drop in their respective international trade flows in 2009, primarily due to the global financial and economic crisis. Third, the countries in our sample have been classified as EMEs based on a wide range of criteria and, therefore, there are high variations in their economic performances in terms of growth, international trade, and technology adoption. In order to have some uniformity among them, we pick 20 countries that are listed by at least three (out of five) agencies. The fact that they are classified as EMEs by multiple agencies suggests that some common criteria have been used and, therefore, we would expect more similarities among them than in the full sample. Fourth, the pooled Durbin-Watson statistics reported in the previous section indicate that we cannot reject the null of no serial correlation in most cases. Therefore, we also estimate a dynamic version of the baseline model with 1-year lagged dependent variable on the right hand side. ${ }^{25}$

Fifth, there are additional variables that may potentially affect trade. We consider the following additional variables: growth of the rest of the world GDP, changes in real exchange rates, average tariff rates, FDI share in total fixed investment, M2-GDP ratio as additional control variables. ${ }^{26}$ The ROW GDP growth creates demand for exports from a country. The effect on imports is not quite clear. While economic growth in the rest of the world increases the supply of imports into a country, growth and higher standard of living in the rest of the world may crowd out some of these imports and the net effect is not clear. The exchange rate appreciation (depreciation) is expected to have a negative (positive) effect on exports and a positive (negative) effect on imports. Lower tariff rates reflect trade openness and are expected to have a direct positive effect on imports and an indirect positive effect on exports. As imports become cheaper, a country may increase imports of capital goods that enhance its ability to export. An increase in FDI share may increase trade as well. When FDI takes place, imports of capital goods rise and exports may also increase particularly when FDIs

\footnotetext{
${ }^{25}$ Since the lagged dependent variable is correlated with country fixed effects, the coefficient estimates are biased and inconsistent. However, our objective for this specification is to examine if the estimates are qualitatively similar to our baseline estimates when we control for any potential autocorrelation in the error terms. Further, some researchers (e.g. Islam 1995) argue that the bias would not be large for moderate size T if $\mathrm{N}$ is relatively large.

${ }^{26}$ Clark and Wallsten (2006) add other variables such as WTO membership, political openness, and a dummy variable for oil exporting countries. In an extended specification we add those variables and do not find any significant differences with respect to the coefficient estimates of the ICT variables. We do not report the results here.
} 
are of efficiency-seeking variety. M2-GDP ratio is used as a measure of financial depth and, as Freund and Weinhold (2002) discuss, serves as a proxy for overall comparative advantages in services across countries. Sixth, we estimate model specifications similar to Choi (2010). Of all the previous studies that we mention, this is the only study that uses total trade instead of bilateral trade as the dependent variable. In this specification, like Choi (2010), we use log-level of all the variables. Finally, it is likely that there are different trends across different countries and, therefore, we include individual time trend for each country in addition to country and year fixed effects in our model.

\section{[Insert Table 8]}

Since our objective is to check if the results with respect to the effects of ICT on trade are robust, we report only the coefficient estimates for the ICT variables from these alternative specifications in Table 8. In the first alternative specification in this section, when we include all four ICT variables together, the estimation procedure uses a much shorter sample period: 1999 - 2004, as the data for Internet hosts are available only for those years. Therefore, for appropriate comparison, we first estimate the baseline model for the sample period: 1999 - 2004, and report the results in the first row of Table 8 . With all four ICT variables together, the estimated coefficients are qualitatively similar in most cases. The noticeable differences are: telecom investment growth has now positive and significant effect on goods and services imports; the effect of Internet bandwidth is now positive in all cases and statistically significant in all but the case of services exports (in both baseline and the alternative specification); the estimated coefficients for Internet subscriptions now turn negative for both exports and imports of services; and Internet hosts are a significant determinant of services exports.

The third row of Panel A and B of Table 8 reproduces the estimated ICT coefficients from the baseline model estimates reported in Table $4 \& 5$ so that they can be compared with the results from the rest of the alternative specifications. With a shorter sample period, $2002-2008$, the coefficient estimates are qualitatively similar to the baseline estimates in most cases. However, the impact of Internet bandwidth is now positive and significant on total and goods exports. Furthermore, the coefficient estimate of Internet hosts in services export equation is not only positive but highly significant. Note that there were significant increases in international Internet bandwidth during this period of time which facilitated substantial data transfer that may have a significant positive impact on trade. With only 20 EMEs, telecom investment growth and Internet bandwidth are not significant in any of the cases. While the coefficient estimates for Internet subscriptions and Internet hosts are qualitatively similar, Internet subscriptions coefficients are slightly smaller in magnitude and those for Internet hosts are slightly larger. The coefficient estimates for the ICT variables, particularly for Internet subscriptions and Internet hosts, are qualitatively very similar when we include 1-year lagged dependent variable. However, they are quantitatively much smaller.

When we include additional control variables, barring a few exceptions, the coefficient estimates for the ICT variables are qualitatively similar to our baseline model estimates. Internet subscriptions and Internet hosts remain significant determinants of exports as well as imports. Finally, when we estimate the model specifications similar to Choi (2010), Internet subscriptions remain a significant determinant of both exports and imports. Internet hosts now do not seem to matter for services 
exports and for total as well as goods imports. However, it has a significant positive impact on services imports. Further, Internet bandwidth has a positive and significant impact on goods as well as services exports, and on total as well as goods imports. Telecom investment growth also becomes a significant determinant of total and goods imports. Our results regarding the impact of Internet hosts on services exports are not quite consistent with the results reported in Choi (2010). However, one needs to recognize that our sample is different: while we use only 40 EMEs, Choi (2010) uses a much larger sample of 151 countries that include both developed and developing countries. In the developed countries, the impact of ICT, particularly on services trade, is expected to be larger.

When individual time trends for different countries are included, the signs of the estimated coefficients for the ICT variables change in 9 (out of total 24) cases but 6 of them are statistically insignificant. Also, the coefficients now become statistically insignificant in 8 cases. In contrast, the coefficient estimates are now significant in 2 cases. Further, the estimated coefficients for Internet hosts remain positive and significant for total exports and goods exports. Internet subscriptions are no longer a significant determinant of total and goods exports. However, this ICT variable has now a significant negative effect on services exports. Also, bandwidth has a significant negative effect on goods exports. The results indicate that Internet hosts have a significant positive impact on total imports and Internet subscriptions have a significant positive effect on goods imports. Additionally, like in the baseline model, bandwidth has a significant positive effect on total imports. However, we need to be careful in interpreting these results. It is important to recognize that including individual time trend makes the coefficient estimates imprecise. It increases the number of parameters to be estimated and thus decreases the degrees of freedom substantially. ${ }^{27}$

Overall, the result that ICT as represented by Internet subscription and Internet hosts, has significant positive impact on export and import shares in emerging market economies is robust to most sensitivity checks that we have considered here. Thus, it is the use of ICT that matters the most for international trade in EMEs.

\section{Concluding Remarks}

This paper examines the effects of ICT on exports and imports in emerging markets. Using panel data for 40 EMEs for a period from 1995 to 2010, we estimate fixed effect models of exports and imports. We use four ICT variables that include growth of investment in telecom services, international Internet bandwidth, Internet subscriptions per 100 people, and the number of Internet hosts per 100 people. The first two ICT variables represent ICT infrastructure while the last two represent ICT use. We use the percentage share of total exports and total imports in GDP as dependent variables. Additionally, we consider the GDP share of exports and imports for goods and services separately. The main control variables are: per capita GDP growth, population growth, and country and year fixed effects. The empirical results overwhelmingly suggest that Internet subscriptions and Internet hosts have significant positive impacts on export as well as import shares in EMEs. This result is robust to a number of sensitivity checks: generalized method of moments

${ }^{27}$ Also, time trend is not statistically significant for a number of countries in our sample. 
(GMM) estimation with lagged independent variables as instruments; inclusion of all four ICT variables together; shorter sample period; a subsample of EMEs; dynamic specification with lagged dependent variable; and an alternative model specification with additional control variables. In general, the results are consistent with those reported by previous studies.

The evidence of trade enhancing impact of ICT is particularly important for developing countries that have been trying to promote international trade. Policies that facilitate and encourage the adoption and use of ICT will go a long way in boosting trade in those countries. The biggest advantage of ICT is that over the years the price of ICT has gone down substantially and it is relatively inexpensive to increase ICT adoption and use. Based on these results, one can also argue that EMEs trying to promote international trade may introduce policies that would increase the use of ICT.

This study uses aggregate data to examine the impact of ICT on exports and imports. Intuitively, ICT may have differential impacts on different trade items. For example, ICT may have a larger impact on trade in financial services than on trade in crude oil. Furthermore, examining the ICT impact on bilateral trade would allow us to control for a wider range of heterogeneity. In our future research, we would like to investigate how ICT affects trade of different items. Furthermore, like most previous studies, we would like to use bilateral trade data. It would allow us to use the gravity model framework that has been the workhorse of the empirical trade literature. 


\section{References}

Acemoglu, D. and D. H. Autor. 2010. "Skills, Tasks and Technologies: Implications for Employment and Earnings.” Mimeo. MIT.

Apte, U M. and R. O. Mason. 1995. "Global Disaggregation of Information-Intensive Services." Management Science, Vol. 41, No. 7: 1250-1262.

Apte, U.M. and H. K. Nath. 2012. "U.S. Trade in Information-Intensive Services." In U.S. Karmarkar and V. Mangal (eds): The UCLA Anderson Business and Information Technologies (BIT) Project: A Global Study of Business Practice, Singapore: World Scientific Books.

Autor, D. H., L. F. Katz, A. B. Krueger. 1998. "Computing Inequality: Have Computers Changed the Labor Market?” The Quarterly Journal of Economics, Vol. 113, No.4: 1169-1213.

Autor, D. H., F. Levy and R. J. Murnane. 2003. “The Skill Content of Recent Technological Change: An Empirical Exploration.” The Quarterly Journal of Economics, Vol. 118, No. 4: 1279-1333.

Basu, S. and J. Fernald. 2007. "Information and Communications Technology as General-Purpose Technology: Evidence from US Industry data." German Economic Review 8(2): 146 - 173.

Choi, C. 2010. “The effect of the Internet on service trade.” Economics Letters 109: 102 - 104.

Clarke, G. R. G. and S. J. Wallsten. 2006. "Has the Internet Increased Trade? Developed and Developing Country Evidence.” Economic Inquiry 44, No. 3: 465-484.

Demirkan, H., M. Goul, R. J. Kauffman, and D. M. Weber. 2009. "Does Distance Matter? The Influence of ICT on Bilateral Trade Flows." Proceedings of the Second Annual SIG GlobDev Workshop, Phoenix USA.

Dimelis, S. P. and S. K. Papaioannou. 2011. "Technical Efficiency and the Role of ICT: A Comparison of Developed and Developing Countries." Emerging Markets Finance \& Trade 47 (Supplement 3): 40-53.

Fink, C. A. Mattoo, and I. C. Neagu. 2005. "Assessing the impact of communication costs on international trade." Journal of International Economics 67, 428-445.

Fleming, E. R.A.E. Mueller, and F. Thiemann. 2009. "ICT and the blooming bloom trade." EFITA Conference '09, 767 - 774.

Frankel, J. A. and D. Romer. 1999. "Does Trade Cause Growth?” American Economic Review, Vol 89 (3): $379-399$.

Freund, C. and D. Weinhold. 2002. "The Internet and International Trade in Services." American Economic Review 92, No. 2: 236 - 240.

Freund, C. and D. Weinhold. 2004. "The effect of the Internet on international trade." Journal of International Economics 62: 171 - 189.

Haacker, M. 2010. "ICT Equipment Investment and Growth in Low-and Lower-Middle-Income Countries." IMF Working Paper WP/10/66.

Hausman, J. and W. Taylor. 1981. "Panel Data and Unobservable Individual Effects." Econometrica 49 (6): $1377-1398$.

Islam, N. 1995. "Growth empirics: A panel data approach.” Quarterly Journal of Economics 110(4): 1127 -1170 . 
Jorgenson, D. W. 2001. "Information Technology and the U.S. Economy." The American Economic Review, Vol. 91, No.1: 1-32.

Kimura, F. and H. H. Lee. 2006. "The Gravity Equation in International Trade in Services." Review of World Economics 142, No. 1: 92 - 121.

Mattes, A. P. Meinen, and F. Pavel. 2012. “Goods Follow Bytes: The Impact of ICT on EU Trade." DIW Berlin Discussion Papers.

Mithas, S. and J. Whitaker. 2007. "Is the World Flat or Spiky? Information Intensity, Skills, and Global Service Disaggregation.” Information Systems Research, Vol. 18: 237-259.

Schreyer, P. 2000. "The Contribution of Information and Communication Technology to Output Growth: A Study of the G7 Countries." OECD Science, Technology and Industry Working Papers $2000 / 02$.

Stiroh, K. J. 2002. "Information Technology and the U.S. Productivity Revival: What Do the Industry Data Say?” The American Economic Review, Vol. 92 No. 5:1559-1576.

Thiemann, F., E. Fleming, and R. A. F. Mueller. 2012. "Impact of information and communication technology (ICT) on international trade in fruit and vegetables: A gravity model approach." Selected paper prepared for presentation at the International Association of Agricultural Economists (LAAE) Triennial Conference, Foz do Iguacu, Brazil, 18-24 August, 2012.

Vemuri, V. K. and S. Siddiqi. 2009. "Impact of Commercialization of the Internet on International Trade: A Panel Study Using the Extended Gravity Model." The International Trade Journal 23, No. 4: $458-484$. 
Table 1 List of Emerging Market Economies (EMEs)

\begin{tabular}{|c|c|c|c|c|c|c|}
\hline Country & FTSE & MSCI & S\&P & Dow Jones & BBVA Research & Common \\
\hline Argentina & & & & & $\mathrm{x}$ & \\
\hline Bahrain & & & & & $\mathrm{x}$ & \\
\hline Bangladesh & & & & & $\mathrm{x}$ & \\
\hline Brazil & $\mathrm{x}$ & $\mathrm{x}$ & $\mathrm{x}$ & $\mathrm{x}$ & $\mathrm{x}$ & $\mathrm{x}$ \\
\hline Bulgaria & & & & & $\mathrm{x}$ & \\
\hline Chile & $\mathrm{x}$ & $\mathrm{x}$ & $\mathrm{x}$ & $\mathrm{x}$ & $\mathrm{x}$ & $\mathrm{x}$ \\
\hline China & $\mathrm{x}$ & $\mathrm{x}$ & $\mathrm{x}$ & $\mathrm{x}$ & $\mathrm{x}$ & $\mathrm{x}$ \\
\hline Colombia & $\mathrm{x}$ & $\mathrm{x}$ & $\mathrm{x}$ & $\mathrm{x}$ & $\mathrm{x}$ & $\mathrm{x}$ \\
\hline Czech Republic & $\mathrm{x}$ & $\mathrm{x}$ & $\mathrm{x}$ & $\mathrm{x}$ & $\mathrm{x}$ & $\mathrm{x}$ \\
\hline Egypt & $\mathrm{x}$ & $\mathrm{x}$ & $\mathrm{x}$ & $\mathrm{x}$ & $\mathrm{x}$ & $\mathrm{x}$ \\
\hline Estonia & & & & & $\mathrm{x}$ & \\
\hline Hungary & $\mathrm{x}$ & $\mathrm{x}$ & $\mathrm{x}$ & $\mathrm{x}$ & $\mathrm{x}$ & $\mathrm{x}$ \\
\hline India & $\mathrm{x}$ & $\mathrm{x}$ & $\mathrm{x}$ & $\mathrm{x}$ & $\mathrm{x}$ & $\mathrm{x}$ \\
\hline Indonesia & $\mathrm{x}$ & $\mathrm{x}$ & $\mathrm{x}$ & $\mathrm{x}$ & $\mathrm{x}$ & $\mathrm{x}$ \\
\hline Iran & & & & & $\mathrm{x}$ & \\
\hline Jordan & & & & & $\mathrm{x}$ & \\
\hline South Korea & & $\mathrm{x}$ & & $\mathrm{x}$ & $\mathrm{x}$ & $\mathrm{x}$ \\
\hline Kuwait & & & & & $\mathrm{x}$ & \\
\hline Latvia & & & & & $\mathrm{x}$ & \\
\hline Lithuania & & & & & $\mathrm{x}$ & \\
\hline Malaysia & $\mathrm{x}$ & $\mathrm{x}$ & $\mathrm{x}$ & $\mathrm{x}$ & $\mathrm{x}$ & $\mathrm{x}$ \\
\hline Mauritius & & & & & $\mathrm{x}$ & \\
\hline Mexico & $\mathrm{x}$ & $\mathrm{x}$ & $\mathrm{x}$ & $\mathrm{x}$ & $\mathrm{x}$ & $\mathrm{x}$ \\
\hline Morocco & $\mathrm{x}$ & $\mathrm{x}$ & $\mathrm{x}$ & $\mathrm{x}$ & $\mathrm{x}$ & $\mathrm{x}$ \\
\hline Nigeria & & & & & $\mathrm{x}$ & \\
\hline Oman & & & & & $\mathrm{x}$ & \\
\hline Pakistan & $\mathrm{x}$ & & & & $\mathrm{x}$ & \\
\hline Peru & $\mathrm{x}$ & $\mathrm{x}$ & $\mathrm{x}$ & $\mathrm{x}$ & $\mathrm{x}$ & $\mathrm{x}$ \\
\hline Philippines & $\mathrm{x}$ & $\mathrm{x}$ & $\mathrm{x}$ & $\mathrm{x}$ & $\mathrm{x}$ & $\mathrm{x}$ \\
\hline Poland & $\mathrm{x}$ & $\mathrm{x}$ & $\mathrm{x}$ & $\mathrm{x}$ & $\mathrm{x}$ & $\mathrm{x}$ \\
\hline Romania & & & & & $\mathrm{x}$ & \\
\hline Russia & $\mathrm{x}$ & $\mathrm{x}$ & $\mathrm{x}$ & $\mathrm{x}$ & $\mathrm{x}$ & $\mathrm{x}$ \\
\hline Slovak Republic & & & & & $\mathrm{x}$ & \\
\hline South Africa & $\mathrm{x}$ & $\mathrm{x}$ & $\mathrm{x}$ & $\mathrm{x}$ & $\mathrm{x}$ & $\mathrm{x}$ \\
\hline Sri Lanka & & & & & $\mathrm{x}$ & \\
\hline Thailand & $\mathrm{x}$ & $\mathrm{x}$ & $\mathrm{x}$ & $\mathrm{x}$ & $\mathrm{x}$ & $\mathrm{x}$ \\
\hline Tunisia & & & & & $\mathrm{x}$ & \\
\hline Turkey & $\mathrm{x}$ & $\mathrm{x}$ & $\mathrm{x}$ & $\mathrm{x}$ & $\mathrm{x}$ & $\mathrm{x}$ \\
\hline Ukraine & & & & & $\mathrm{x}$ & \\
\hline Vietnam & & & & & $\mathrm{x}$ & \\
\hline
\end{tabular}

Note: This list has been compiled from the latest reports published by various agencies listed in the top row. The last column "Common" indicates that a country has been identified as an EME by at least three agencies. 
Table 2 Summary statistics of the major variables

\begin{tabular}{|c|c|c|c|c|c|c|c|c|c|c|}
\hline \multirow{2}{*}{ Variables } & \multicolumn{5}{|c|}{ Mean } & \multicolumn{5}{|c|}{ Standard Deviation } \\
\hline & Overall & & Min & & Max & Overall & & Min & & Max \\
\hline $\begin{array}{l}\% \text { share of exports in } \\
\text { GDP }\end{array}$ & 44.84 & 10.39 & (Argentina) & 111.26 & (Malaysia) & 24.65 & 0.73 & (South Africa) & 24.82 & (Hungary) \\
\hline $\begin{array}{l}\% \text { share of goods } \\
\text { exports in GDP }\end{array}$ & 35.55 & 8.79 & (Argentina) & 97.38 & (Malaysia) & 21.04 & 0.61 & (South Africa) & 27.55 & (Nigeria) \\
\hline $\begin{array}{l}\% \text { share of services } \\
\text { exports in GDP }\end{array}$ & 9.03 & 1.50 & (Iran) & 25.35 & (Estonia) & 6.34 & 0.07 & (Bangladesh) & 6.37 & (Philippines \\
\hline $\begin{array}{l}\% \text { share of import in } \\
\text { GDP }\end{array}$ & 45.62 & 11.31 & (Argentina) & 95.87 & (Malaysia) & 24.35 & 0.88 & (Argentina) & 23.70 & (Hungary) \\
\hline $\begin{array}{l}\% \text { share of goods } \\
\text { import in GDP }\end{array}$ & 37.25 & 8.41 & (Argentina) & 77.16 & (Malaysia) & 20.03 & 0.59 & (Bangladesh) & 21.59 & (Hungary) \\
\hline $\begin{array}{l}\% \text { of services import } \\
\text { in GDP }\end{array}$ & 8.52 & 2.62 & (Brazil) & 17.84 & (Jordan) & 4.91 & 0.12 & (Colombia) & 9.04 & (Nigeria) \\
\hline $\begin{array}{l}\text { Telecom investment } \\
\text { growth }\end{array}$ & 12.52 & -10.86 & (Argentina) & 67.15 & (Ukraine) & 62.74 & 3.72 & (Vietnam) & 194.53 & (Nigeria) \\
\hline $\begin{array}{l}\text { Log of Internet } \\
\text { bandwidth }\end{array}$ & 7.57 & 3.64 & (Mauritius) & 10.34 & (Czech Republic) & 3.31 & 1.1 & (Bahrain) & 4.60 & (Bulgaria) \\
\hline $\begin{array}{l}\text { Internet } \\
\text { subscriptions per } 100 \\
\text { people }\end{array}$ & 5.04 & 0.05 & (Bangladesh) & 19.79 & (South Korea) & 6.49 & 0.03 & (Bangladesh) & 13.43 & $\begin{array}{l}\text { (Russian } \\
\text { Federation) }\end{array}$ \\
\hline $\begin{array}{l}\text { Internet hosts per } \\
100 \text { people }\end{array}$ & 0.64 & 0.0004 & (Vietnam) & 3.96 & (South Korea) & 1.24 & 0.0002 & (Vietnam) & 4.53 & $\begin{array}{l}\text { (South } \\
\text { Korea) }\end{array}$ \\
\hline $\begin{array}{l}\text { Per capita GDP } \\
\text { growth }\end{array}$ & 2.96 & -0.38 & (Colombia) & 8.65 & (China) & 4.13 & 0.50 & (Bangladesh) & 8.03 & (Ukraine) \\
\hline Population growth & 0.96 & -0.89 & (Latvia) & 3.29 & (Kuwait) & 1.10 & 0.02 & (Vietnam) & 1.54 & (Kuwait) \\
\hline
\end{tabular}

Note: The name of the country that has the minimum or the maximum value of the relevant variable is in bracket. 
Table 3 Average correlations between trade variables and ICT variables across 40 EMEs, 1995 - 2010

\begin{tabular}{lcccc}
\hline & $\begin{array}{c}\text { Telecom Investment } \\
\text { Growth }\end{array}$ & $\begin{array}{c}\text { Natural log of Internet } \\
\text { bandwidth }\end{array}$ & $\begin{array}{c}\text { Internet subscriptions } \\
\text { per 100 people }\end{array}$ & $\begin{array}{c}\text { Internet hosts per 100 } \\
\text { people }\end{array}$ \\
\hline Export share & $(1)$ & $(2)$ & $(3)$ & $(4)$ \\
Goods export share & 0.008 & 0.43 & 0.48 & 0.47 \\
& $(-0.45,0.69)$ & $(-0.83,0.97)$ & $(-0.97,0.96)$ & $(-0.80,0.99)$ \\
Services export share & 0.02 & 0.51 & 0.51 & 0.53 \\
& $(-0.73,0.67)$ & $(-0.93,0.97)$ & $(-0.95,0.95)$ & $(-0.95,0.99)$ \\
Import share & 0.04 & 0.35 & 0.29 & 0.19 \\
& $(-0.60,0.94)$ & $(-0.93,0.98)$ & $(-0.93,0.94)$ & $(-0.90,0.92)$ \\
Goods import share & 0.11 & 0.43 & 0.40 & 0.49 \\
Services import share & $(-0.51,0.88)$ & $(-0.86,0.96)$ & $(-0.90,0.97)$ & $(-0.88,0.998)$ \\
& 0.15 & 0.48 & 0.44 & 0.44 \\
& $(-0.67,0.86)$ & $(-0.91,0.95)$ & $(-0.80,0.98)$ & $(-0.97,0.99)$ \\
\end{tabular}

Note: The minimum and maximum correlation coefficients are in parentheses. Since data on some ICT variables are available only for 2 to 3 years in Iran, Kuwait, and Vietnam, the correlation coefficients with trade variables are 1 (perfect correlation). However, we do not report those correlation coefficients as the maximum values because they are outliers. 
Table 4 ICT and export share: Fixed effects panel estimates for 40 EMEs

\begin{tabular}{|c|c|c|c|c|c|c|c|c|c|c|c|c|}
\hline \multirow{3}{*}{$\begin{array}{l}\text { Independent } \\
\text { Variables }\end{array}$} & \multicolumn{12}{|c|}{ Dependent Variables } \\
\hline & \multicolumn{4}{|c|}{ Export share } & \multicolumn{4}{|c|}{ Goods export share } & \multicolumn{4}{|c|}{ Services export share } \\
\hline & $(1)$ & $(2)$ & (3) & (4) & $(5)$ & (6) & $(7)$ & (8) & $(9)$ & $(10)$ & $(11)$ & $(12)$ \\
\hline $\begin{array}{l}\text { Telecom } \\
\text { investment }\end{array}$ & $-0.012^{*}$ & & & & -0.012 & & & & 0.0004 & & & \\
\hline Growth & $(0.007)$ & & & & $(0.008)$ & & & & $(0.001)$ & & & \\
\hline Natural log of & & -0.232 & & & & 0.178 & & & & 0.057 & & \\
\hline $\begin{array}{l}\text { Internet } \\
\text { bandwidth }\end{array}$ & & $(0.678)$ & & & & $(0.743)$ & & & & $(0.100)$ & & \\
\hline $\begin{array}{l}\text { Internet } \\
\text { subscription }\end{array}$ & & & $0.729 * * *$ & & & & $0.679 * * *$ & & & & $0.084 * * *$ & \\
\hline $\begin{array}{l}\text { per } 100 \\
\text { people }\end{array}$ & & & $(0.155)$ & & & & $(0.129)$ & & & & $(0.017)$ & \\
\hline Internet hosts & & & & $0.721 * * *$ & & & & $0.770^{* * *}$ & & & & -0.007 \\
\hline $\begin{array}{l}\text { per } 100 \\
\text { people }\end{array}$ & & & & $(0.099)$ & & & & $(0.084)$ & & & & $(0.022)$ \\
\hline Per capita & -0.088 & -0.115 & -0.115 & $0.212^{* * *}$ & -0.120 & $-0.127 *$ & -0.116 & $0.175^{* *}$ & -0.010 & $-0.044^{* *}$ & $-0.026^{*}$ & 0.001 \\
\hline GDP growth & $(0.094)$ & $(0.082)$ & $(0.110)$ & $(0.061)$ & $(0.090)$ & $(0.071)$ & $(0.141)$ & $(0.074)$ & $(0.022)$ & $(0.018)$ & $(0.015)$ & $(0.025)$ \\
\hline Population & 0.776 & $0.964 * * *$ & $1.151 * * *$ & $2.402 * * *$ & $1.695^{*}$ & $3.494 * * *$ & $2.516^{* *}$ & $2.215^{* * *}$ & 0.154 & 0.204 & 0.119 & -0.127 \\
\hline growth & $(0.534)$ & $(0.253)$ & $(0.269)$ & $(0.615)$ & $(0.911)$ & $(0.957)$ & $(1.200)$ & $(0.636)$ & $(0.167)$ & $(0.143)$ & $(0.103)$ & $(0.104)$ \\
\hline R-squared & 0.901 & 0.928 & 0.930 & 0.975 & 0.894 & 0.931 & 0.919 & 0.971 & 0.933 & 0.953 & 0.943 & 0.979 \\
\hline $\begin{array}{l}\text { Adj R- } \\
\text { squared }\end{array}$ & 0.887 & 0.919 & 0.920 & 0.969 & 0.878 & 0.921 & 0.907 & 0.963 & 0.922 & 0.946 & 0.934 & 0.973 \\
\hline $\begin{array}{l}\text { Durbin- } \\
\text { Watson stat }\end{array}$ & 0.345 & 0.446 & 0.405 & 1.081 & 0.391 & 0.446 & 0.442 & 1.190 & 0.486 & 0.628 & 0.531 & 1.228 \\
\hline $\begin{array}{l}\text { Number of } \\
\text { observations }\end{array}$ & 444 & 492 & 447 & 240 & 430 & 463 & 430 & 234 & 430 & 463 & 430 & 234 \\
\hline $\begin{array}{l}\text { Number of } \\
\text { countries }\end{array}$ & 40 & 40 & 40 & 40 & 40 & 40 & 40 & 40 & 40 & 40 & 40 & 40 \\
\hline
\end{tabular}

Note:***Significant at 1\% level; ** significant at 5\% level; * significant at $10 \%$ level. Cluster-robust standard errors are reported in parentheses. 
Table 5 ICT and import share: Fixed effects panel estimates for 40 EMEs

\begin{tabular}{|c|c|c|c|c|c|c|c|c|c|c|c|c|}
\hline \multirow{3}{*}{$\begin{array}{l}\text { Independent } \\
\text { Variables }\end{array}$} & \multicolumn{12}{|c|}{ Dependent Variables } \\
\hline & \multicolumn{4}{|c|}{ Import share } & \multicolumn{4}{|c|}{ Goods import share } & \multicolumn{4}{|c|}{ Services import share } \\
\hline & (1) & (2) & (3) & (4) & (5) & (6) & $(7)$ & (8) & $(9)$ & $(10)$ & (11) & $(12)$ \\
\hline \multirow{2}{*}{$\begin{array}{l}\text { Telecom } \\
\text { investment } \\
\text { Growth }\end{array}$} & $-0.010^{*}$ & & & & -0.007 & & & & 0.002 & & & \\
\hline & $(0.005)$ & & & & $(0.006)$ & & & & $(0.001)$ & & & \\
\hline Natural log of & & $1.513^{* * *}$ & & & & $1.187^{*}$ & & & & 0.004 & & \\
\hline $\begin{array}{l}\text { Internet } \\
\text { bandwidth }\end{array}$ & & $(0.532)$ & & & & $(0.615)$ & & & & $(0.103)$ & & \\
\hline \multirow{2}{*}{$\begin{array}{l}\text { Internet } \\
\text { subscriptions per } \\
100 \text { people }\end{array}$} & & \multicolumn{3}{|c|}{$0.629 * * *$} & \multicolumn{4}{|c|}{$0.513^{* * *}$} & & \multicolumn{3}{|c|}{$0.106^{* * *}$} \\
\hline & & \multicolumn{3}{|c|}{$(0.101)$} & \multicolumn{4}{|c|}{$(0.076)$} & & & $(0.017)$ & \\
\hline \multirow{2}{*}{$\begin{array}{l}\text { Internet hosts per } \\
100 \text { people }\end{array}$} & & & & $0.616^{* * *}$ & & & & $0.510^{* * *}$ & & & & $0.080 * *$ \\
\hline & & & & $(0.110)$ & & & & $(0.154)$ & & & & $(0.032)$ \\
\hline Per capita GDP & $0.148^{* *}$ & 0.055 & 0.053 & 0.155 & 0.123 & 0.089 & 0.122 & 0.116 & -0.012 & $-0.053 * * *$ & $-0.044^{* *}$ & $-0.067 * * *$ \\
\hline growth & $(0.069)$ & $(0.076)$ & $(0.106)$ & $(0.104)$ & $(0.077)$ & $(0.080)$ & $(0.110)$ & $(0.078)$ & $(0.023)$ & $(0.015)$ & $(0.020)$ & $(0.019)$ \\
\hline \multirow{2}{*}{ Population growth } & $3.490 * * *$ & 0.453 & 0.486 & $2.374 * *$ & $2.781 * * *$ & $3.754 * * *$ & $3.243^{* * *}$ & $1.866^{* *}$ & $0.507 * *$ & $0.387 * * *$ & 0.334 & 0.408 \\
\hline & $(0.651)$ & $(0.490)$ & $(0.501)$ & $(0.925)$ & $(0.774)$ & $(0.610)$ & $(0.690)$ & $(0.851)$ & $(0.211)$ & $(0.140)$ & $(0.206)$ & $(0.293)$ \\
\hline R-squared & 0.917 & 0.946 & 0.941 & 0.976 & 0.915 & 0.941 & 0.938 & 0.967 & 0.875 & 0.926 & 0.894 & 0.967 \\
\hline $\begin{array}{l}\text { Adjusted R- } \\
\text { squared }\end{array}$ & 0.905 & 0.939 & 0.933 & 0.971 & 0.902 & 0.933 & 0.929 & 0.959 & 0.857 & 0.916 & 0.879 & 0.958 \\
\hline $\begin{array}{l}\text { Durbin-Watson } \\
\text { Stat }\end{array}$ & 0.384 & 0.477 & 0.457 & 0.957 & 0.465 & 0.568 & 0.580 & 0.974 & 0.413 & 0.596 & 0.461 & 1.168 \\
\hline $\begin{array}{l}\text { Number of } \\
\text { Observations }\end{array}$ & 444 & 492 & 447 & 240 & 430 & 463 & 430 & 234 & 430 & 463 & 430 & 234 \\
\hline $\begin{array}{l}\text { Number of } \\
\text { Countries }\end{array}$ & 40 & 40 & 40 & 40 & 40 & 40 & 40 & 40 & 40 & 40 & 40 & 40 \\
\hline
\end{tabular}

Note: $* * *$ Significant at $1 \%$ level; $* *$ significant at $5 \%$ level; $*$ significant at $10 \%$ level. Cluster-robust standard errors are in parentheses. 
Table 6 Results from baseline model estimates with 1, 2, and 3-year lagged ICT variables

\begin{tabular}{|c|c|c|c|c|c|c|}
\hline & $\begin{array}{l}\text { Export } \\
\text { Share }\end{array}$ & $\begin{array}{l}\text { Goods } \\
\text { Export } \\
\text { Share }\end{array}$ & $\begin{array}{l}\text { Services } \\
\text { Export } \\
\text { Share }\end{array}$ & $\begin{array}{l}\text { Import } \\
\text { Share }\end{array}$ & $\begin{array}{l}\text { Goods } \\
\text { Import } \\
\text { Share }\end{array}$ & $\begin{array}{l}\text { Services } \\
\text { Import } \\
\text { Share }\end{array}$ \\
\hline & $(1)$ & $(2)$ & (3) & (4) & $(5)$ & $(6)$ \\
\hline \multicolumn{7}{|c|}{ Panel A: 1-year lagged ICT variables } \\
\hline $\begin{array}{l}\text { Telecom investment } \\
\text { growth }\end{array}$ & $\begin{array}{l}-0.012 \\
(0.009)\end{array}$ & $\begin{array}{c}-0.019 * * * \\
(0.007)\end{array}$ & $\begin{array}{l}-0.001 \\
(0.001)\end{array}$ & $\begin{array}{l}-0.007 \\
(0.004)\end{array}$ & $\begin{array}{l}-0.010^{*} \\
(0.006)\end{array}$ & $\begin{array}{l}0.0005 \\
(0.002)\end{array}$ \\
\hline $\begin{array}{l}\text { Natural log of } \\
\text { Internet bandwidth }\end{array}$ & $\begin{array}{c}0.151 \\
(0.796)\end{array}$ & $\begin{array}{c}0.687 \\
(0.841)\end{array}$ & $\begin{array}{c}0.016 \\
(0.090)\end{array}$ & $\begin{array}{l}1.481^{* *} \\
(0.634)\end{array}$ & $\begin{array}{l}1.112^{*} \\
(0.598)\end{array}$ & $\begin{array}{l}-0.050 \\
(0.108)\end{array}$ \\
\hline $\begin{array}{l}\text { Internet } \\
\text { subscriptions per } \\
100 \text { people }\end{array}$ & $\begin{array}{c}0.594 * * * \\
(0.094)\end{array}$ & $\begin{array}{c}0.602^{* * *} \\
(0.070)\end{array}$ & $\begin{array}{c}0.060^{* * *} \\
(0.020)\end{array}$ & $\begin{array}{c}0.595^{* * *} \\
(0.071)\end{array}$ & $\begin{array}{c}0.444 * * * \\
(0.061)\end{array}$ & $\begin{array}{c}0.090 * * * \\
(0.020)\end{array}$ \\
\hline $\begin{array}{l}\text { Internet hosts per } \\
100 \text { people }\end{array}$ & $\begin{array}{c}0.937^{* * *} \\
(0.211) \\
\end{array}$ & $\begin{array}{c}0.499 * * * \\
(0.190) \\
\end{array}$ & $\begin{array}{c}0.074^{* *} \\
(0.030) \\
\end{array}$ & $\begin{array}{c}0.425^{* *} \\
(0.165) \\
\end{array}$ & $\begin{array}{c}0.206^{* *} \\
(0.103)\end{array}$ & $\begin{array}{c}0.079 * * \\
(0.034)\end{array}$ \\
\hline \multicolumn{7}{|c|}{ Panel B: 2-year lagged ICT variables } \\
\hline $\begin{array}{l}\text { Telecom investment } \\
\text { growth }\end{array}$ & $\begin{array}{l}-0.016 \\
(0.010)\end{array}$ & $\begin{array}{l}-0.011 * \\
(0.006)\end{array}$ & $\begin{array}{l}0.0003 \\
(0.002)\end{array}$ & $\begin{array}{l}-0.015^{* * *} \\
(0.004)\end{array}$ & $\begin{array}{l}-0.013 \\
(0.003)\end{array}$ & $\begin{array}{l}-0.0002 \\
(0.001)\end{array}$ \\
\hline $\begin{array}{l}\text { Natural log of } \\
\text { Internet bandwidth }\end{array}$ & $\begin{array}{c}0.795 \\
(0.573)\end{array}$ & $\begin{array}{l}1.013^{*} \\
(0.529)\end{array}$ & $\begin{array}{l}-0.116 \\
(0.091)\end{array}$ & $\begin{array}{l}1.316^{* *} \\
(0.527)\end{array}$ & $\begin{array}{c}0.828^{* *} \\
(0.399)\end{array}$ & $\begin{array}{l}-0.093 \\
(0.094)\end{array}$ \\
\hline $\begin{array}{l}\text { Internet } \\
\text { subscriptions per } \\
100 \text { people }\end{array}$ & $\begin{array}{c}0.798^{* * *} \\
(0.160)\end{array}$ & $\begin{array}{c}0.719^{* * *} \\
(0.110)\end{array}$ & $\begin{array}{c}0.095^{* * *} \\
(0.024)\end{array}$ & $\begin{array}{c}0.698^{* * *} \\
(0.124)\end{array}$ & $\begin{array}{c}0.475^{* * *} \\
(0.072)\end{array}$ & $\begin{array}{c}0.128^{* * *} * \\
(0.036)\end{array}$ \\
\hline $\begin{array}{l}\text { Internet hosts per } \\
100 \text { people }\end{array}$ & $\begin{array}{c}1.398 * * * \\
(0.310) \\
\end{array}$ & $\begin{array}{c}0.790^{* *} \\
(0.320) \\
\end{array}$ & $\begin{array}{c}0.091 * * * \\
(0.029) \\
\end{array}$ & $\begin{array}{c}0.858^{* * *} \\
(0.241) \\
\end{array}$ & $\begin{array}{c}0.532^{* * *} \\
(0.188) \\
\end{array}$ & $\begin{array}{c}0.123^{* * * *} \\
(0.029) \\
\end{array}$ \\
\hline \multicolumn{7}{|c|}{ Panel C: 3-year lagged ICT variables } \\
\hline $\begin{array}{l}\text { Telecom investment } \\
\text { growth }\end{array}$ & $\begin{array}{c}-0.021 * * \\
(0.009)\end{array}$ & $\begin{array}{l}-0.005 \\
(0.006)\end{array}$ & $\begin{array}{c}0.002 \\
(0.001)\end{array}$ & $\begin{array}{c}-0.012^{* *} \\
(0.006)\end{array}$ & $\begin{array}{l}-0.002 \\
(0.005)\end{array}$ & $\begin{array}{c}0.002 \\
(0.002)\end{array}$ \\
\hline $\begin{array}{l}\text { Natural log of } \\
\text { Internet bandwidth }\end{array}$ & $\begin{array}{c}0.811 \\
(0.524)\end{array}$ & $\begin{array}{c}1.225^{* * *} \\
(0.444)\end{array}$ & $\begin{array}{l}-0.053 \\
(0.074)\end{array}$ & $\begin{array}{l}0.897 * \\
(0.471)\end{array}$ & $\begin{array}{l}0.746^{* *} \\
(0.358)\end{array}$ & $\begin{array}{l}-0.076 \\
(0.064)\end{array}$ \\
\hline $\begin{array}{l}\text { Internet } \\
\text { subscriptions per } \\
100 \text { people }\end{array}$ & $\begin{array}{c}0.713^{* * *} \\
(0.112)\end{array}$ & $\begin{array}{c}0.617 * * * \\
(0.123)\end{array}$ & $\begin{array}{c}0.093^{* * *} \\
(0.015)\end{array}$ & $\begin{array}{c}0.483^{* * *} \\
(0.089)\end{array}$ & $\begin{array}{c}0.329 * * * \\
(0.057)\end{array}$ & $\begin{array}{c}0.087 * * * \\
(0.009)\end{array}$ \\
\hline $\begin{array}{l}\text { Internet hosts per } \\
100 \text { people }\end{array}$ & $\begin{array}{c}2.017 * * * \\
(0.272)\end{array}$ & $\begin{array}{c}1.421 * * * \\
(0.244)\end{array}$ & $\begin{array}{c}0.134 * * * \\
(0.020)\end{array}$ & $\begin{array}{c}1.280^{* * *} \\
(0.235)\end{array}$ & $\begin{array}{c}0.925^{* * *} \\
(0.144)\end{array}$ & $\begin{array}{c}0.215^{* * *} \\
(0.027)\end{array}$ \\
\hline
\end{tabular}


Table 7 Results from the GMM estimates of the baseline model with lagged independent variables as instruments

\begin{tabular}{|c|c|c|c|c|c|c|}
\hline & $\begin{array}{l}\text { Export } \\
\text { Share }\end{array}$ & $\begin{array}{l}\text { Goods } \\
\text { Export } \\
\text { Share }\end{array}$ & $\begin{array}{l}\text { Services } \\
\text { Export } \\
\text { Share } \\
\end{array}$ & $\begin{array}{l}\text { Import } \\
\text { Share }\end{array}$ & $\begin{array}{l}\text { Goods } \\
\text { Import } \\
\text { Share }\end{array}$ & $\begin{array}{l}\text { Services } \\
\text { Import } \\
\text { Share }\end{array}$ \\
\hline & (1) & (2) & (3) & (4) & (5) & (6) \\
\hline $\begin{array}{l}\text { Telecom investment } \\
\text { growth }\end{array}$ & $\begin{array}{c}0.079 \\
(0.059)\end{array}$ & $\begin{array}{c}0.158 \\
(0.139)\end{array}$ & $\begin{array}{c}0.012 \\
(0.014)\end{array}$ & $\begin{array}{c}0.052 \\
(0.050)\end{array}$ & $\begin{array}{c}0.155 \\
(0.110)\end{array}$ & $\begin{array}{c}0.014 \\
(0.015)\end{array}$ \\
\hline $\begin{array}{l}\text { Natural log of } \\
\text { Internet bandwidth }\end{array}$ & $\begin{array}{c}0.543 \\
(1.543)\end{array}$ & $\begin{array}{c}0.876 \\
(1.771)\end{array}$ & $\begin{array}{c}0.005 \\
(0.235)\end{array}$ & $\begin{array}{c}2.702^{* *} \\
(1.300)\end{array}$ & $\begin{array}{c}1.160 \\
(1.539)\end{array}$ & $\begin{array}{l}-0.252 \\
(0.262)\end{array}$ \\
\hline $\begin{array}{l}\text { Internet } \\
\text { subscriptions per } \\
100 \text { people }\end{array}$ & $\begin{array}{c}0.875^{* * *} \\
(0.307)\end{array}$ & $\begin{array}{c}0.799 * * * \\
(0.305)\end{array}$ & $\begin{array}{c}0.140 * * * \\
(0.049)\end{array}$ & $\begin{array}{c}0.825^{* * *} \\
(0.238)\end{array}$ & $\begin{array}{c}0.614^{* * *} \\
(0.146)\end{array}$ & $\begin{array}{c}0.175^{* * *} \\
(0.052)\end{array}$ \\
\hline $\begin{array}{l}\text { Internet hosts per } \\
100 \text { people }\end{array}$ & $\begin{array}{c}1.270 \\
(0.838)\end{array}$ & $\begin{array}{c}1.308^{* * *} \\
(0.477)\end{array}$ & $\begin{array}{l}-0.038 \\
(0.093)\end{array}$ & $\begin{array}{c}0.344^{* *} \\
(0.165)\end{array}$ & $\begin{array}{c}0.204 \\
(0.170)\end{array}$ & $\begin{array}{c}0.079 \\
(0.131)\end{array}$ \\
\hline \multicolumn{7}{|l|}{ Hansen's J-statistics } \\
\hline $\begin{array}{l}\text { Telecom investment } \\
\text { growth }\end{array}$ & $\begin{array}{l}1.466 \\
(0.226)\end{array}$ & $\begin{array}{c}0.586 \\
(0.444)\end{array}$ & $\begin{array}{c}0.001 \\
(0.972)\end{array}$ & $\begin{array}{c}0.002 \\
(0.965)\end{array}$ & $\begin{array}{c}0.002 \\
(0.960)\end{array}$ & $\begin{array}{c}0.280 \\
(0.950)\end{array}$ \\
\hline $\begin{array}{l}\text { Natural log of } \\
\text { Internet bandwidth }\end{array}$ & $\begin{array}{c}5.257 \\
(0.022)\end{array}$ & $\begin{array}{l}2.490 \\
(0.115)\end{array}$ & $\begin{array}{l}2.751 \\
(0.097)\end{array}$ & $\begin{array}{c}0.625 \\
(0.429)\end{array}$ & $\begin{array}{c}0.017 \\
(0.895)\end{array}$ & $\begin{array}{c}0.437 \\
(0.509)\end{array}$ \\
\hline $\begin{array}{l}\text { Internet } \\
\text { subscriptions per } \\
100 \text { people }\end{array}$ & $\begin{array}{c}0.461 \\
(0.497)\end{array}$ & $\begin{array}{c}0.093 \\
(0.760)\end{array}$ & $\begin{array}{c}0.695 \\
(0.404)\end{array}$ & $\begin{array}{c}0.135 \\
(0.714)\end{array}$ & $\begin{array}{l}1.036 \\
(0.309)\end{array}$ & $\begin{array}{c}0.120 \\
(0.0729)\end{array}$ \\
\hline $\begin{array}{l}\text { Internet hosts per } \\
100 \text { people }\end{array}$ & $\begin{array}{l}2 \mathrm{e}-05 \\
(0.996)\end{array}$ & $\begin{array}{c}0.004 \\
(0.950)\end{array}$ & $\begin{array}{c}0.378 \\
(0.539)\end{array}$ & $\begin{array}{c}0.133 \\
(0.715)\end{array}$ & $\begin{array}{c}0.007 \\
(0.935)\end{array}$ & $\begin{array}{c}0.728 \\
(0.0394)\end{array}$ \\
\hline
\end{tabular}

Note: 1 -year lags of relevant ICT variable and population growth, and 1- and 2-year lags of per capita GDP are used as instruments. The null hypothesis of Hansen's J test is that the instruments are valid. The numbers in parentheses under the estimated $J$-statistics are $p$-values. 
Table 8 Sensitivity analysis results

Panel A. Exports

\begin{tabular}{|c|c|c|c|c|c|c|c|c|c|c|c|c|}
\hline \multirow{3}{*}{$\begin{array}{l}\text { Model } \\
\text { specifications }\end{array}$} & \multicolumn{4}{|c|}{ Total exports } & \multicolumn{4}{|c|}{ Goods exports } & \multicolumn{4}{|c|}{ Services exports } \\
\hline & $\mathrm{TI}$ & $\mathrm{BD}$ & IS & $\mathrm{IH}$ & TI & $\mathrm{BD}$ & IS & $\mathrm{IH}$ & TI & $\mathrm{BD}$ & IS & $\mathrm{IH}$ \\
\hline & $(1)$ & $(2)$ & (3) & (4) & (5) & (6) & $(7)$ & (8) & (9) & $(10)$ & $(11)$ & $(12)$ \\
\hline $\begin{array}{l}\text { Baseline for } \\
\text { 1999-2004 }\end{array}$ & $\begin{array}{c}0.001 \\
(0.005)\end{array}$ & $\begin{array}{c}2.152^{* * *} \\
(0.680)\end{array}$ & $\begin{array}{c}0.373 * * \\
(0.151)\end{array}$ & $\begin{array}{c}0.721 * * * \\
(0.099)\end{array}$ & $\begin{array}{l}-0.001 \\
(0.007)\end{array}$ & $\begin{array}{c}2.215^{* * *} \\
(0.744)\end{array}$ & $\begin{array}{c}0.470^{* * *} \\
(0.174)\end{array}$ & $\begin{array}{c}0.770^{* * *} \\
(0.084)\end{array}$ & $\begin{array}{c}0.002 \\
(0.001)\end{array}$ & $\begin{array}{c}0.148 \\
(0.102)\end{array}$ & $\begin{array}{c}-0.027 * * \\
(0.011)\end{array}$ & $\begin{array}{l}-0.007 \\
(0.022)\end{array}$ \\
\hline $\begin{array}{l}\text { All four ICT } \\
\text { variables } \\
\text { together }\end{array}$ & $\begin{array}{c}0.001 \\
(0.005)\end{array}$ & $\begin{array}{l}1.341 * \\
(0.755)\end{array}$ & $\begin{array}{c}0.202^{* * *} \\
(0.055)\end{array}$ & $\begin{array}{c}0.725^{* * *} \\
(0.191)\end{array}$ & $\begin{array}{c}-0.0003 \\
(0.008)\end{array}$ & $\begin{array}{l}1.606^{*} \\
(0.832)\end{array}$ & $\begin{array}{c}0.300^{* *} \\
(0.119)\end{array}$ & $\begin{array}{c}0.540 * * * \\
(0.199)\end{array}$ & $\begin{array}{c}0.002 \\
(0.002)\end{array}$ & $\begin{array}{c}0.060 \\
(0.129)\end{array}$ & $\begin{array}{c}-0.062 * * * \\
(0.017)\end{array}$ & $\begin{array}{c}0.136 * * * \\
(0.032)\end{array}$ \\
\hline Baseline Model & $\begin{array}{l}-0.012 * \\
(0.007)\end{array}$ & $\begin{array}{c}-0.232 \\
(0.678)\end{array}$ & $\begin{array}{c}0.729 * * * \\
(0.155)\end{array}$ & $\begin{array}{c}0.721 * * * \\
(0.099)\end{array}$ & $\begin{array}{c}-0.012 \\
(0.008)\end{array}$ & $\begin{array}{c}0.178 \\
(0.743)\end{array}$ & $\begin{array}{c}0.679 * * \\
(0.129)\end{array}$ & $\begin{array}{c}0.770 * * * \\
(0.084)\end{array}$ & $\begin{array}{l}0.0004 \\
(0.001)\end{array}$ & $\begin{array}{c}0.057 \\
(0.100)\end{array}$ & $\begin{array}{c}0.084 * * * \\
(0.017)\end{array}$ & $\begin{array}{c}0.007 \\
(0.022)\end{array}$ \\
\hline $\begin{array}{l}\text { Sample period: } \\
2002 \text { - } 2008\end{array}$ & $\begin{array}{l}-0.006 \\
(0.011)\end{array}$ & $\begin{array}{c}1.111^{* * *} \\
(0.056)\end{array}$ & $\begin{array}{c}0.364^{* *} \\
(0.150)\end{array}$ & $\begin{array}{c}0.664 * * * \\
(0.087)\end{array}$ & $\begin{array}{c}-0.016^{* *} \\
(0.011)\end{array}$ & $\begin{array}{c}-1.488^{* *} \\
(0.610)\end{array}$ & $\begin{array}{c}0.686 * * * \\
(0.137)\end{array}$ & $\begin{array}{c}0.564 * * * \\
(0.038)\end{array}$ & $\begin{array}{c}-6.5 e-5 \\
(0.0002)\end{array}$ & $\begin{array}{l}-0.146 \\
(0.159)\end{array}$ & $\begin{array}{c}0.026 \\
(0.023)\end{array}$ & $\begin{array}{c}0.064^{* *} \\
(0.026)\end{array}$ \\
\hline 20 countries & $\begin{array}{l}-0.006 \\
(0.007)\end{array}$ & $\begin{array}{l}-0.888 \\
(0.919)\end{array}$ & $\begin{array}{c}0.449 * * \\
(0.181)\end{array}$ & $\begin{array}{c}0.953 * * * \\
(0.101)\end{array}$ & $\begin{array}{l}-0.011 \\
(0.008)\end{array}$ & $\begin{array}{l}-0.540 \\
(0.836)\end{array}$ & $\begin{array}{c}0.451 * * * \\
(0.145)\end{array}$ & $\begin{array}{c}0.961 * * * \\
(0.110)\end{array}$ & $\begin{array}{l}0.0004 \\
(0.003)\end{array}$ & $\begin{array}{c}0.048 \\
(0.122)\end{array}$ & $\begin{array}{c}0.075^{* *} \\
(0.033)\end{array}$ & $\begin{array}{c}0.010 \\
(0.037)\end{array}$ \\
\hline $\begin{array}{l}\text { With 1-year } \\
\text { lagged dependent } \\
\text { variable }\end{array}$ & $\begin{array}{l}-0.001 \\
(0.004)\end{array}$ & $\begin{array}{l}-0.109 \\
(0.270)\end{array}$ & $\begin{array}{c}0.138^{* * *} \\
(0.050)\end{array}$ & $\begin{array}{c}0.549 * * * \\
(0.087)\end{array}$ & $\begin{array}{l}-0.004 \\
(0.006)\end{array}$ & $\begin{array}{c}0.378 \\
(0.281)\end{array}$ & $\begin{array}{c}0.077 \\
(0.078)\end{array}$ & $\begin{array}{c}0.669^{* * *} \\
(0.106)\end{array}$ & $\begin{array}{l}0.0004 \\
(0.001)\end{array}$ & $\begin{array}{l}-0.067 \\
(0.072)\end{array}$ & $\begin{array}{c}0.023 * * \\
(0.011)\end{array}$ & $\begin{array}{l}-0.020 \\
(0.028)\end{array}$ \\
\hline $\begin{array}{l}\text { Additional } \\
\text { variables }\end{array}$ & $\begin{array}{c}-0.011^{*} \\
(0.006)\end{array}$ & $\begin{array}{l}-0.473 \\
(0.851)\end{array}$ & $\begin{array}{c}0.388^{* * *} \\
(0.143)\end{array}$ & $\begin{array}{c}0.692 * * * \\
(0.111)\end{array}$ & $\begin{array}{c}-0.012^{* *} \\
(0.006)\end{array}$ & $\begin{array}{c}0.096 \\
(0.719)\end{array}$ & $\begin{array}{c}0.488^{* * *} \\
(0.138)\end{array}$ & $\begin{array}{c}0.770^{* * *} \\
(0.199)\end{array}$ & $\begin{array}{c}-0.003^{* * *} \\
(0.001)\end{array}$ & $\begin{array}{c}0.078 \\
(0.125)\end{array}$ & $\begin{array}{l}0.033^{*} \\
(0.020)\end{array}$ & $\begin{array}{c}0.033 \\
(0.042)\end{array}$ \\
\hline $\begin{array}{l}\text { Choi (2010) } \\
\text { specification }\end{array}$ & $\begin{array}{l}-0.001 \\
(0.006)\end{array}$ & $\begin{array}{c}0.014 \\
(0.012)\end{array}$ & $\begin{array}{c}0.061 * * * \\
(0.015)\end{array}$ & $\begin{array}{c}0.006 * * \\
(0.003)\end{array}$ & $\begin{array}{c}0.004 \\
(0.009)\end{array}$ & $\begin{array}{c}0.031 * * \\
(0.014)\end{array}$ & $\begin{array}{c}0.054 * * * \\
(0.013)\end{array}$ & $\begin{array}{c}0.017 * * * \\
(0.003)\end{array}$ & $\begin{array}{c}0.017 \\
(0.024)\end{array}$ & $\begin{array}{l}0.017 * \\
(0.009)\end{array}$ & $\begin{array}{c}0.061 * * * \\
(0.015)\end{array}$ & $\begin{array}{c}0.009 \\
(0.007)\end{array}$ \\
\hline $\begin{array}{l}\text { With individual } \\
\text { time trend for } \\
\text { each country }\end{array}$ & $\begin{array}{l}4 . e-05 \\
(0.004)\end{array}$ & $\begin{array}{l}-0.285 \\
(0.218)\end{array}$ & $\begin{array}{l}-0.128 \\
(0.092)\end{array}$ & $\begin{array}{c}0.596^{* * *} \\
(0.170)\end{array}$ & $\begin{array}{c}0.000 \\
(0.006)\end{array}$ & $\begin{array}{c}-0.785^{* * *} \\
(0.190)\end{array}$ & $\begin{array}{c}0.047 \\
(0.084)\end{array}$ & $\begin{array}{c}0.686^{* * *} \\
(0.201)\end{array}$ & $\begin{array}{c}0.001 \\
(0.001)\end{array}$ & $\begin{array}{c}0.131 \\
(0.117)\end{array}$ & $\begin{array}{c}-0.072^{* * *} \\
(0.016)\end{array}$ & $\begin{array}{l}-0.003 \\
(0.031)\end{array}$ \\
\hline
\end{tabular}

Notes: 1. TI: Telecom investment growth; BD: Internet bandwidth; IS: Internet subscriptions; IH: Internet hosts.

2. ***Significant at $1 \%$ level; ** significant at $5 \%$ level; * significant at $10 \%$ level. Cluster-robust standard errors are in parentheses.

3. These 20 countries include Brazil, Chile, China, Colombia, Czech Republic, Egypt, Hungary, India, Indonesia, Korea, Malaysia, Mexico, Morocco, Peru, Philippines, Poland, Russia, South Africa, Thailand, and Turkey

4. Additional control variables: Rest of the world GDP growth, change in real exchange rate, percentage share of FDI in fixed domestic investment, average tariffs, M2-GDP ratio (measure of financial depth) 
Table 8 Sensitivity analysis results

Panel B: Imports

\begin{tabular}{|c|c|c|c|c|c|c|c|c|c|c|c|c|}
\hline \multirow{3}{*}{$\begin{array}{l}\text { Model } \\
\text { specifications }\end{array}$} & \multicolumn{4}{|c|}{ Total imports } & \multicolumn{4}{|c|}{ Goods imports } & \multicolumn{4}{|c|}{ Services imports } \\
\hline & TI & $\mathrm{BD}$ & IS & $\mathrm{IH}$ & TI & $\mathrm{BD}$ & IS & $\mathrm{IH}$ & TI & $\mathrm{BD}$ & IS & $\mathrm{IH}$ \\
\hline & (1) & $(2)$ & (3) & (4) & (5) & (6) & $(7)$ & (8) & (9) & $(10)$ & $(11)$ & $(12)$ \\
\hline $\begin{array}{l}\text { Baseline for } \\
\text { 1999-2004 }\end{array}$ & $\begin{array}{c}0.002 \\
(0.006)\end{array}$ & $\begin{array}{c}2.275^{* * *} \\
(0.673)\end{array}$ & $\begin{array}{c}0.522^{* * *} \\
(0.135)\end{array}$ & $\begin{array}{c}0.616^{* * *} \\
(0.110)\end{array}$ & $\begin{array}{c}-0.0002 \\
(0.005)\end{array}$ & $\begin{array}{c}2.243^{* * *} \\
(0.566)\end{array}$ & $\begin{array}{c}0.441 * * * \\
(0.099)\end{array}$ & $\begin{array}{c}0.510 * * * \\
(0.154)\end{array}$ & $\begin{array}{c}0.002 \\
(0.002)\end{array}$ & $\begin{array}{c}0.196 * * * \\
(0.054)\end{array}$ & $\begin{array}{c}0.022^{* *} \\
(0.010)\end{array}$ & $\begin{array}{c}0.080 * * \\
(0.032)\end{array}$ \\
\hline $\begin{array}{l}\text { All four ICT } \\
\text { variables }\end{array}$ & $\begin{array}{c}0.010 \\
(0.008)\end{array}$ & $\begin{array}{c}1.899 * * * \\
(0.706)\end{array}$ & $\begin{array}{c}0.279 * * * \\
(0.093)\end{array}$ & $\begin{array}{c}0.409 * * * \\
(0.117)\end{array}$ & $\begin{array}{l}0.009 * \\
(0.005)\end{array}$ & $\begin{array}{c}1.680 * * * \\
(0.597)\end{array}$ & $\begin{array}{c}0.340 * * * \\
(0.059)\end{array}$ & $\begin{array}{l}0.244^{*} \\
(0.128)\end{array}$ & $\begin{array}{c}0.003^{* * *} \\
(0.001)\end{array}$ & $\begin{array}{c}0.255^{* *} \\
(0.126)\end{array}$ & $\begin{array}{l}-0.032 \\
(0.030)\end{array}$ & $\begin{array}{l}0.143^{*} \\
(0.077)\end{array}$ \\
\hline $\begin{array}{l}\text { Baseline } \\
\text { Model }\end{array}$ & $\begin{array}{l}-0.010 * \\
(0.005)\end{array}$ & $\begin{array}{c}1.513 * * * \\
(0.532)\end{array}$ & $\begin{array}{c}0.629 * * * \\
(0.101)\end{array}$ & $\begin{array}{c}0.616 * * * \\
(0.110)\end{array}$ & $\begin{array}{l}-0.007 \\
(0.006)\end{array}$ & $\begin{array}{l}1.187^{*} \\
(0.615)\end{array}$ & $\begin{array}{c}0.513 * * * \\
(0.076)\end{array}$ & $\begin{array}{c}0.510 * * * \\
(0.154)\end{array}$ & $\begin{array}{c}0.002 \\
(0.001)\end{array}$ & $\begin{array}{c}0.004 \\
(0.103)\end{array}$ & $\begin{array}{c}0.106 * * * \\
(0.017)\end{array}$ & $\begin{array}{c}0.080 * * \\
(0.032)\end{array}$ \\
\hline $\begin{array}{l}\text { Sample period: } \\
2002-2008\end{array}$ & $\begin{array}{c}-0.010^{* *} \\
(0.005)\end{array}$ & $\begin{array}{c}1.287 * * * \\
(0.443)\end{array}$ & $\begin{array}{c}0.803^{* * *} \\
(0.132)\end{array}$ & $\begin{array}{c}0.344^{* * *} \\
(0.085)\end{array}$ & $\begin{array}{l}-0.005 \\
(0.009)\end{array}$ & $\begin{array}{c}0.216 \\
(0.609)\end{array}$ & $\begin{array}{c}0.667^{* * *} \\
(0.102)\end{array}$ & $\begin{array}{c}0.306^{* * *} \\
(0.086)\end{array}$ & $\begin{array}{c}0.001 \\
(0.001)\end{array}$ & $\begin{array}{l}-0.184 \\
(0.127)\end{array}$ & $\begin{array}{c}0.069 * * \\
(0.027)\end{array}$ & $\begin{array}{c}0.064 * * * \\
(0.012)\end{array}$ \\
\hline 20 countries & $\begin{array}{c}0.003 \\
(0.010)\end{array}$ & $\begin{array}{l}-0.609 \\
(0.735)\end{array}$ & $\begin{array}{c}0.428^{* * *} \\
(0.105)\end{array}$ & $\begin{array}{c}0.659 * * * \\
(0.136)\end{array}$ & $\begin{array}{l}0.0004 \\
(0.008)\end{array}$ & $\begin{array}{l}-0.283 \\
(0.610)\end{array}$ & $\begin{array}{c}0.415^{* * *} \\
(0.089)\end{array}$ & $\begin{array}{c}0.738^{* * *} \\
(0.170)\end{array}$ & $\begin{array}{l}-0.001 \\
(0.001)\end{array}$ & $\begin{array}{c}0.071 \\
(0.137)\end{array}$ & $\begin{array}{c}0.099 * * * \\
(0.027)\end{array}$ & $\begin{array}{c}0.156^{* * *} \\
(0.049)\end{array}$ \\
\hline $\begin{array}{l}\text { With 1-year } \\
\text { lagged } \\
\text { dependent } \\
\text { variable }\end{array}$ & $\begin{array}{l}-0.0004 \\
(0.005)\end{array}$ & $\begin{array}{c}0.125 \\
(0.276)\end{array}$ & $\begin{array}{c}0.139 * * \\
(0.058)\end{array}$ & $\begin{array}{c}0.543^{* * *} \\
(0.149)\end{array}$ & $\begin{array}{c}0.003 \\
(0.006)\end{array}$ & $\begin{array}{c}0.261 \\
(0.242)\end{array}$ & $\begin{array}{c}0.173^{* * * *} \\
(0.050)\end{array}$ & $\begin{array}{c}0.341 * * \\
(0.155)\end{array}$ & $\begin{array}{c}0.002 \\
(0.002)\end{array}$ & $\begin{array}{l}-0.068 \\
(0.045)\end{array}$ & $\begin{array}{l}0.026^{*} \\
(0.015)\end{array}$ & $\begin{array}{c}0.072 * * \\
(0.029)\end{array}$ \\
\hline $\begin{array}{l}\text { Additional } \\
\text { variables }\end{array}$ & $\begin{array}{l}-0.009 \\
(0.007)\end{array}$ & $\begin{array}{c}0.955 \\
(0.582)\end{array}$ & $\begin{array}{c}0.373^{* * *} \\
(0.107)\end{array}$ & $\begin{array}{c}0.488^{* * *} \\
(0.120)\end{array}$ & $\begin{array}{l}-0.006 \\
(0.005)\end{array}$ & $\begin{array}{c}0.774 \\
(0.569)\end{array}$ & $\begin{array}{c}0.404^{* * *} \\
(0.082)\end{array}$ & $\begin{array}{c}0.362^{* * *} \\
(0.123)\end{array}$ & $\begin{array}{l}0.0001 \\
(0.001)\end{array}$ & $\begin{array}{l}-0.004 \\
(0.124)\end{array}$ & $\begin{array}{c}0.074^{* * *} * \\
(0.021)\end{array}$ & $\begin{array}{l}0.105^{* *} \\
((0.051)\end{array}$ \\
\hline $\begin{array}{l}\text { Choi (2010) } \\
\text { specification }\end{array}$ & $\begin{array}{c}0.030^{* * *} \\
(0.011)\end{array}$ & $\begin{array}{c}0.015^{* *} \\
(0.007)\end{array}$ & $\begin{array}{c}0.052^{* * *} \\
(0.010)\end{array}$ & $\begin{array}{c}0.014 \\
(0.008)\end{array}$ & $\begin{array}{c}0.024 * * * \\
(0.006)\end{array}$ & $\begin{array}{c}0.020^{* *} \\
(0.008)\end{array}$ & $\begin{array}{c}0.059 * * * \\
(0.010)\end{array}$ & $\begin{array}{c}0.005 \\
(0.005)\end{array}$ & $\begin{array}{c}0.010 \\
(0.010)\end{array}$ & $\begin{array}{l}-0.005 \\
(0.009)\end{array}$ & $\begin{array}{c}0.050^{* * *} \\
(0.017)\end{array}$ & $\begin{array}{c}0.014^{* * *} \\
(0.005)\end{array}$ \\
\hline $\begin{array}{l}\text { With individual } \\
\text { time trend for } \\
\text { each country }\end{array}$ & $\begin{array}{c}0.003 \\
(0.004)\end{array}$ & $\begin{array}{c}0.878^{* * *} \\
(0.261)\end{array}$ & $\begin{array}{c}0.022 \\
(0.066)\end{array}$ & $\begin{array}{c}0.367 * * \\
(0.161)\end{array}$ & $\begin{array}{c}0.006^{* *} \\
(0.003)\end{array}$ & $\begin{array}{c}0.191 \\
(0.221)\end{array}$ & $\begin{array}{c}0.199 * * \\
(0.090)\end{array}$ & $\begin{array}{c}0.096 \\
(0.124)\end{array}$ & $\begin{array}{c}0.003^{* *} \\
(0.001)\end{array}$ & $\begin{array}{c}0.071 \\
(0.094)\end{array}$ & $\begin{array}{l}-0.018 \\
(0.018)\end{array}$ & $\begin{array}{l}-0.011 \\
(0.033)\end{array}$ \\
\hline
\end{tabular}

Notes: 1. TI: Telecom investment growth; BD: Internet bandwidth; IS: Internet subscriptions; IH: Internet hosts.

2. ***Significant at 1\% level; ** significant at 5\% level; * significant at $10 \%$ level. Cluster-robust standard errors are in parentheses.

3. These 20 countries include Brazil, Chile, China, Colombia, Czech Republic, Egypt, Hungary, India, Indonesia, Korea, Malaysia, Mexico, Morocco, Peru, Philippines, Poland, Russia, South Africa, Thailand, and Turkey

4. Additional control variables: Rest of the world GDP growth, change in real exchange rate, percentage share of FDI in fixed domestic investment, average tariffs, M2-GDP ratio (measure of financial depth) 
Table A.1 Variables Description

\begin{tabular}{|c|c|c|c|}
\hline Variable name & Variable description & Years available & Data source \\
\hline Telecom Investment & $\begin{array}{l}\text { Gross investment in Telecom in current } \\
\text { USD. }\end{array}$ & $1995-2010$ & International Telecommunication Union \\
\hline Internet bandwidth & $\begin{array}{l}\text { Total capacity of international Internet } \\
\text { bandwidth in Mega Bits Per Second } \\
(\mathrm{Mbit} / \mathrm{s}) \text {. }\end{array}$ & $1995-2010$ & International Telecommunication Union \\
\hline Internet subscriptions & $\begin{array}{l}\text { The number of total Internet subscriptions } \\
\text { with fixed (wired) Internet access. }\end{array}$ & $1995-2010$ & International Telecommunication Union \\
\hline Internet hosts & The total number of Internet Hosts. & 1999-2004 & International Telecommunication Union \\
\hline Total export & $\begin{array}{l}\text { Exports of goods and services in constant } \\
2000 \text { US\$. }\end{array}$ & $1995-2010$ & World Development Indicators (WDI) \\
\hline Total import & $\begin{array}{l}\text { Imports of goods and services in constant } \\
2000 \text { US\$. }\end{array}$ & $1995-2010$ & World Development Indicators (WDI) \\
\hline Total goods export & Goods exports, BoP, in current US\$ & $1995-2010$ & World Development Indicators (WDI) \\
\hline Total goods import & Goods imports, BoP, in current US\$ & $1995-2010$ & World Development Indicators (WDI) \\
\hline Total services export & Service exports, BoP, in current US\$ & $1995-2010$ & World Development Indicators (WDI) \\
\hline Total services import & Service imports, BoP, in current US\$ & $1995-2010$ & World Development Indicators (WDI) \\
\hline GDP per capita & GDP per capita in constant 2000 US\$ & $1995-2010$ & World Development Indicators (WDI) \\
\hline Local GDP & Local GDP in constant 2000 US\$ & $1995-2010$ & World Development Indicators (WDI) \\
\hline World GDP & World GDP in constant 2000 US\$ & $1995-2010$ & World Development Indicators (WDI) \\
\hline Population & Total population & $1995-2010$ & World Development Indicators (WDI) \\
\hline Exchange rate & Nominal exchange rate & $1995-2010$ & Penn World Table 7 \\
\hline FDI net inflow & $\begin{array}{l}\text { Net inflows of Foreign direct investment, } \\
\text { BoP, in current US\$ }\end{array}$ & $1995-2010$ & Global Development Finance (GDF) \\
\hline Fixed domestic investment & $\begin{array}{l}\text { Gross fixed capital formation in constant } \\
2000 \text { US\$ }\end{array}$ & $1995-2010$ & Global Development Finance (GDF) \\
\hline Tariffs & $\begin{array}{l}\text { Simple average of tariff rate in percentages, } \\
\text { applied on all products }\end{array}$ & $1995-2010$ & World Development Indicators (WDI) \\
\hline Consumer price index & Consumer price index , $2005=100$ & $1995-2010$ & World Development Indicators (WDI) \\
\hline M2 & Money supply measure & $1995-2010$ & Global Development Finance (GDF) \\
\hline
\end{tabular}

